Article

\title{
Cu-Doped ZnO Nanoparticles for Non-Enzymatic Glucose Sensing
}

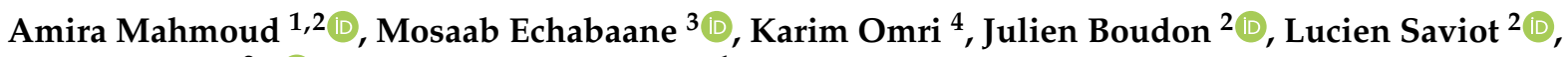 \\ Nadine Millot ${ }^{2, *}$ (D) and Rafik Ben Chaabane ${ }^{1}$
}

1 Laboratory Interfaces and Advanced Materials (LIMA), Faculty of Science of Monastir, University of Monastir, 5019 Monastir, Tunisia; Amira_Mahmoud@etu.u-bourgogne.fr (A.M.); Rafik.benchaabane@fsm.rnu.tn (R.B.C.)

2 Laboratoire Interdisciplinaire Carnot de Bourgogne (ICB), UMR 6303 CNRS, Université Bourgogne Franche-Comté, 9 av. A. Savary, BP 47870, 21078 Dijon, France; Julien.Boudon@u-bourgogne.fr (J.B.); Lucien.Saviot@u-bourgogne.fr (L.S.)

3 NANOMISENE Lab., LR16CRMN01, Centre for Research on Microelectronics and Nanotechnology CRMN of Technopark of Sousse, B.P. 334, Sahloul, 4034 Sousse, Tunisia; mosaab.echabaane@gmail.com

4 Laboratory of Physics of Materials and Nanomaterials Applied at Environment (LaPhyMNE), Faculty of Sciences of Gabes, University of Gabes, 6029 Gabes, Tunisia; omrikarim16@gmail.com

* Correspondence: nmillot@u-bourgogne.fr; Tel.: +33-380-395-937

Citation: Mahmoud, A.; Echabaane, M.; Omri, K.; Boudon, J.; Saviot, L.; Millot, N.; Chaabane, R.B. Cu-Doped $\mathrm{ZnO}$ Nanoparticles for Non-Enzymatic Glucose Sensing. Molecules 2021, 26, 929. https://doi.org/10.3390/ molecules26040929

Academic Editor: Lucian Baia Received: 10 December 2020

Accepted: 5 February 2021

Published: 10 February 2021

Publisher's Note: MDPI stays neutral with regard to jurisdictional claims in published maps and institutional affiliations.

Copyright: (c) 2021 by the authors. Licensee MDPI, Basel, Switzerland. This article is an open access article distributed under the terms and conditions of the Creative Commons Attribution (CC BY) license (https:// creativecommons.org/licenses/by/ $4.0 /)$.

\begin{abstract}
Copper-doped zinc oxide nanoparticles (NPs) $\mathrm{Cu}_{x} \mathrm{Zn}_{1-x} \mathrm{O}(x=0,0.01,0.02,0.03$, and 0.04 ) were synthesized via a sol-gel process and used as an active electrode material to fabricate a non-enzymatic electrochemical sensor for the detection of glucose. Their structure, composition, and chemical properties were characterized using X-ray diffraction (XRD), transmission electron microscopy (TEM), Fourier-transform infrared (FTIR) and Raman spectroscopies, and zeta potential measurements. The electrochemical characterization of the sensors was studied using cyclic voltammetry (CV), electrochemical impedance spectroscopy (EIS), and differential pulse voltammetry (DPV). $\mathrm{Cu}$ doping was shown to improve the electrocatalytic activity for the oxidation of glucose, which resulted from the accelerated electron transfer and greatly improved electrochemical conductivity. The experimental conditions for the detection of glucose were optimized: a linear dependence between the glucose concentration and current intensity was established in the range from $1 \mathrm{nM}$ to $100 \mu \mathrm{M}$ with a limit of detection of $0.7 \mathrm{nM}$. The proposed sensor exhibited high selectivity for glucose in the presence of various interfering species. The developed sensor was also successfully tested for the detection of glucose in human serum samples.
\end{abstract}

Keywords: $\mathrm{ZnO}$; $\mathrm{Cu}$ doping; nanoparticles; electrochemistry; glucose; non-enzymatic sensor

\section{Introduction}

Nanoscale semiconducting metal oxides have been triggering extensive research activities owing to their unique electronic, mechanical, and optical properties [1]. Their good crystallinity and large surface-to-volume ratio make them good candidates for producing highly sensitive chemical sensors [2]. In particular, nanoparticles (NPs) made of $\mathrm{ZnO}$, a wide band-gap semiconductor, are attracting a lot of attention due to their low-temperature synthesis, various morphologies, high crystallinity, good optical properties, and excellent electrical characteristics. ZnO has a broad range of applications in photocatalysis [3], photovoltaics [4], gas sensing [5], electronics (diodes), and water-splitting [6]. It has also received growing interest in the field of biochemical sensors [7] thanks to its outstanding sensitivity to chemical species. NPs have a large surface-to-volume ratio. This improves their sensing properties compared to flat $\mathrm{ZnO}$ surfaces by multiplying the interactions at the molecular level with surrounding chemical species [8]. Furthermore, the high isoelectric point (IEP) of $\mathrm{ZnO}$ [9] allows its surface to adsorb biocatalysts with a low IEP via electrostatic interactions. In addition, its unique physico-chemical behavior, high electron 
transfer capability, and high reactivity with oxygen make $\mathrm{ZnO}$ one of the most promising semiconductor metal oxides for many applications and have led to rapid progress in the development of (bio)chemical sensors [10].

Despite the outstanding properties of $\mathrm{ZnO}$ nanostructures, the sensing capability of pure $\mathrm{ZnO}$ was found to be inadequate [11]. Recent studies have shown that the combination of $\mathrm{ZnO}$ nanostructures with catalyst species (noble metals, transition metals, carbon nanotubes, graphene, etc.) can overcome this issue. These various catalyst species allow for the creation of $\mathrm{ZnO}$-based nanostructures with a large surface area for catalysis, short diffusion pathways for charge carriers, and efficient electron transport. Doping ZnO NPs with transition metals, such as $\mathrm{Al}$ [12], Mn [13], Co [14], Ni [15], and Fe [16], has revealed a significant impact on the electrical, optical, and magnetic properties that might enhance the sensing response [17]. $\mathrm{Cu}$ is frequently used as a doping transition metal to develop $\mathrm{ZnO}$ $\mathrm{NPs}$ with improved properties for advanced applications. Indeed, $\mathrm{Cu}$ atoms can substitute $\mathrm{Zn}$ in the $\mathrm{ZnO}$ lattice structure thanks to their identical valence state and similar ionic radii [18]. In addition, $\mathrm{Cu}$ has a large ionization energy and low formation energy, which speeds up the integration of $\mathrm{Cu}$ into the $\mathrm{ZnO}$ lattice [19]. The incorporation of $\mathrm{Cu}$ into $\mathrm{ZnO}$ provides a high electronic conductivity and good donor defects. This facilitates the charge separation and improves the transport properties in $\mathrm{ZnO}$ nanostructures [20].

Despite quite similar radii for $\mathrm{Cu}^{2+}$ and $\mathrm{Zn}^{2+}$ cations $\left(\mathrm{Cu}^{2+}: 0.73 \AA\right.$, $\left.\mathrm{Zn}^{2+}: 0.74 \AA\right)$ [18], relatively low values of $\mathrm{Cu}$ content can be incorporated in the $\mathrm{ZnO}$ wurtzite structure, without the phases demixing. In the case of $\mathrm{Cu}$-doped $\mathrm{ZnO}$ nanorods synthesized using an ice-bath-assisted sonochemical technique, Othman et al. [21] reported a single phase (wurtzite) up to a doping content of $4 \% \mathrm{Cu}$. For higher $\mathrm{Cu}$ content, a $\mathrm{CuO}$ secondary phase appeared, which generated distortions in the $\mathrm{ZnO}$ host lattice. Similar behavior was reported by Lee et al. [22], who synthesized $\mathrm{Cu}$-doped $\mathrm{ZnO}$ using a sol-gel method, and by Chandekar et al. [23], who prepared Cu-doped ZnO NPs using the auto combustion method. Therefore, mixed phases (metallic copper, copper oxides, or any binary zinc copper phase) mostly appear for $5 \%$ Cu doping.

Sensing with Cu-based nanomaterial is extremely sensitive thanks to its good electrochemical activity and proper redox potentials. $\mathrm{Cu}$ is an efficient electrical conductor at a low overpotential. The large surface area and chemical properties of $\mathrm{Cu}$ NPs provide high adsorption rates and strong interactions with analytes [24]. Cu NPs also possess catalytically active sites with enhanced electron transfer rates [25].

Recently, glucose biochemical sensors based on $\mathrm{ZnO}$ nanostructures have attracted considerable interest. Glucose is a critical component in the blood that provides energy for living organisms. Abnormal levels of glucose are the source of multiple medical disorders. They play a major role in the initiation and development of diabetes mellitus, one of the major causes of death in the world [26]. Regulating and controlling glucose is therefore a major health issue. Improving glucose-sensing devices with fast, reliable, and sensitive recognition of the glucose levels has become an absolute requirement in order to meet the needs of diabetes patients and also for other non-medical areas of interest, including biotechnology and food-processing industries [27].

The electrochemical approach stands out among the various possible techniques that are suitable for glucose determination [28]. Two main kinds of glucose sensors are used in electrochemical technology: enzymatic-based sensing and non-enzymatic glucose sensing $[29,30]$. Most of the previous glucose sensors relied on enzymes to electrocatalyze the oxidation of glucose [31]. The advantages of enzymatic glucose biosensors are their excellent selectivity and high sensitivity. However, they present drawbacks, such as poor vitality and reduced chemical and thermodynamic stability, which originate from the intrinsic nature of enzymes. In addition, their high cost, complicated immobilization procedures, rigorous operating conditions (appropriate temperature, $\mathrm{pH}$, humidity, and toxic chemicals), and poor reproducibility further limit their development [32,33]. To overcome these shortcomings, non-enzymatic glucose sensors are being considered due 
to their potential advantages, including a simple fabrication process, improved stability under different conditions, reproducibility, and low cost [34].

In a previous study [35], we reported the development of pure and copper-doped $\mathrm{ZnO}$ NPs (one composition) as a form of non-enzymatic glucose detection. Herein, we study the impacts of varying $\mathrm{Cu}$ doping concentration on the physicochemical properties of ZnO NPs for improved non-enzymatic glucose sensing. The influence of Cu doping on the structural, morphological, and chemical properties of ZnO NPs was studied in detail using X-ray diffraction (XRD), transmission electron microscopy (TEM), zeta potential measurements, and Fourier-transform infrared (FTIR) and Raman spectroscopies. We developed a procedure to coat the NPs on indium-doped tin oxide (ITO) to fabricate sensing electrodes. The electrochemical properties of the $\mathrm{Cu}_{x} \mathrm{Zn}_{1-x} \mathrm{O}$ NP-based electrodes were studied using cyclic voltammetry, electrochemical impedance spectroscopy, and differential pulse voltammetry. We were thus able to identify the optimal $\mathrm{Cu}$ content that presented outstanding features, such as high sensitivity, selectivity, a wide linear range, and a low limit of detection. These excellent performances, together with the easy fabrication process, make this approach promising for developing low-cost, non-enzymatic electrochemical sensors for the determination of glucose contents.

\section{Results and Discussion}

\subsection{Structural and Morphological Characterization and Chemical Studies of $C u_{x} \mathrm{Zn}_{1-x} \mathrm{O} N P_{S}$}

The X-ray diffraction patterns of $\mathrm{Cu}_{x} \mathrm{Zn}_{1-x} \mathrm{O}$ NPs $(x=0,0.01,0.02,0.03$, and 0.04) are shown in Figure 1. The (100), (002), (101), (102), and (110) Bragg peaks matched with the hexagonal phase of $\mathrm{ZnO}$ (International Centre for Diffraction Data (ICDD) 36-1451). These peaks were sharp and intense, which proved the high crystallinity of the NPs as also highlighted by the SAED (selected area electron diffraction) pattern and highresolution transmission electron microscopy (HR-TEM) analysis (Figure 2a,b). In Figure 2a, the diffraction rings were relatively continuous, in agreement with the nanosize of the crystallites. The rings of the $\mathrm{Cu}_{0.04} \mathrm{Zn}_{0.96} \mathrm{O}$ sample could be indexed to the (100), (002), (101), (102), and (110) planes of hexagonal wurtzite ZnO. The HR-TEM image (Figure 2b) clearly depicts the presence of aligned lattice fringes with interplane spacings of $0.28 \mathrm{~nm}$ and 0.26 $\mathrm{nm}$, corresponding to the (100) and (002) lattice planes of wurtzite $\mathrm{ZnO}$, respectively. Hence, the SAED pattern and HR-TEM analysis were in good accordance with the XRD. For the doped samples, no new diffraction peaks related to possible $\mathrm{Cu}$-rich phases were observed in the XRD patterns. This proves that the $\mathrm{Cu}$ ions were completely incorporated into the $\mathrm{ZnO}$ lattice and did not cause a change in the structure since the doping concentration was below the solubility limit [36]. It is noteworthy to mention that when the Cu doping was increased to $x=0.05$, the XRD patterns of the NPs presented extra peaks related to the $\mathrm{Cu}$ segregated phases (see Supplementary Information, Figure S1).
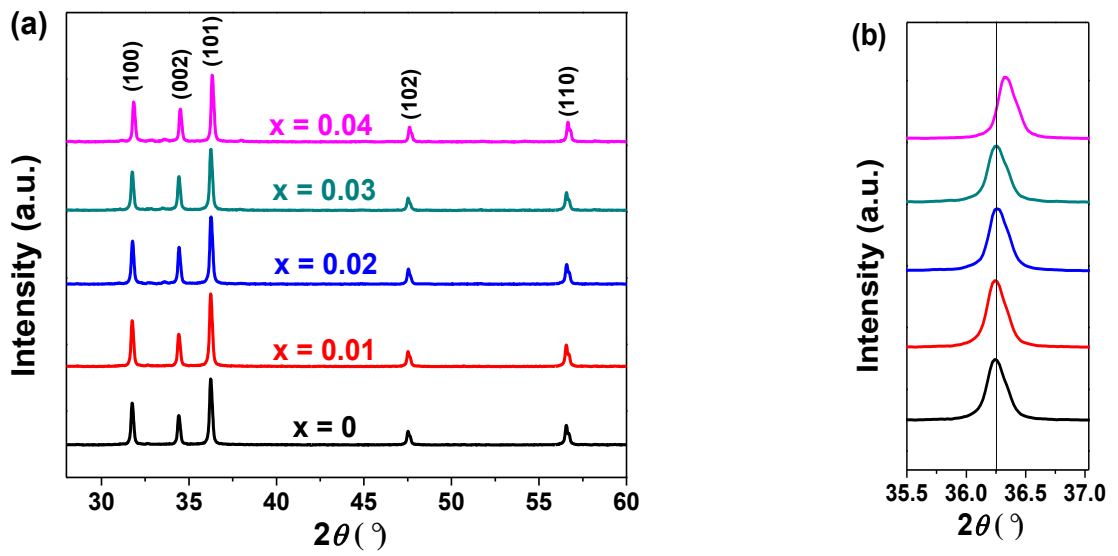

Figure 1. (a) X-ray diffraction (XRD) patterns of $\mathrm{Cu}_{x} \mathrm{Zn}_{1-x} \mathrm{O}$ nanoparticles (NPs) $(x=0,0.01,0.02$, 0.03 , and 0.04 ) and (b) the enlarged view of the (101) peak. 


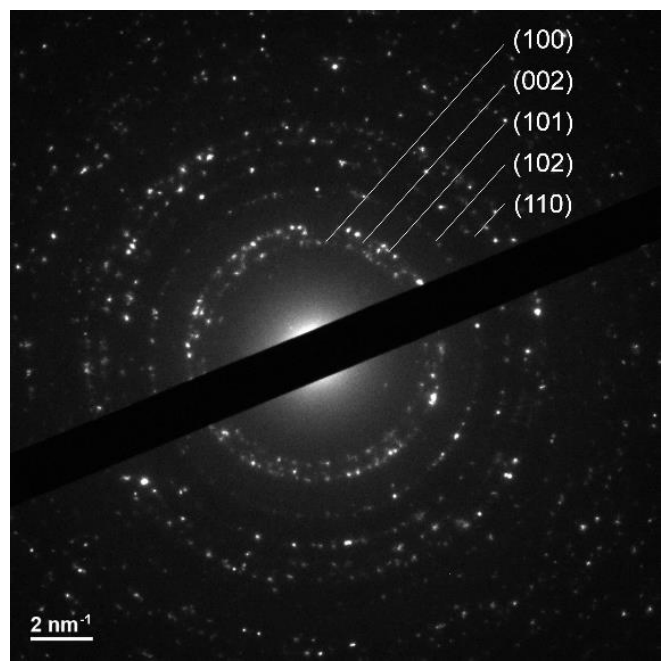

(a)

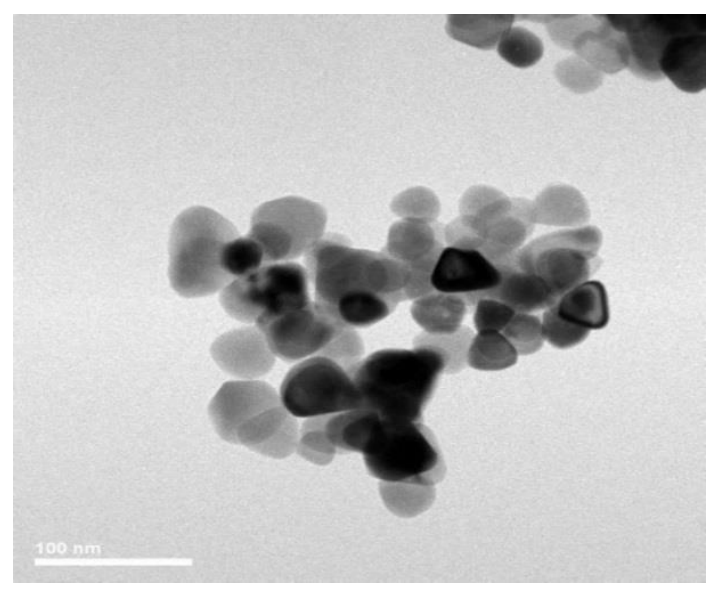

(c)

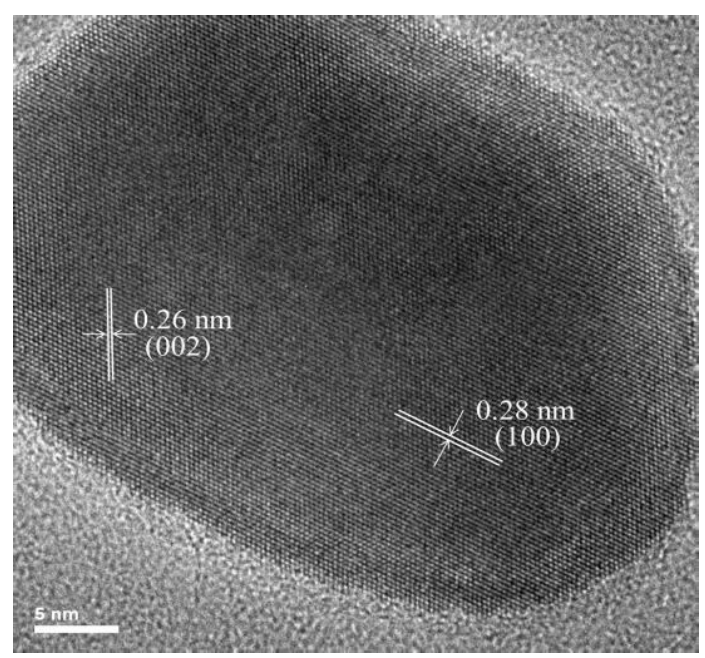

(b)

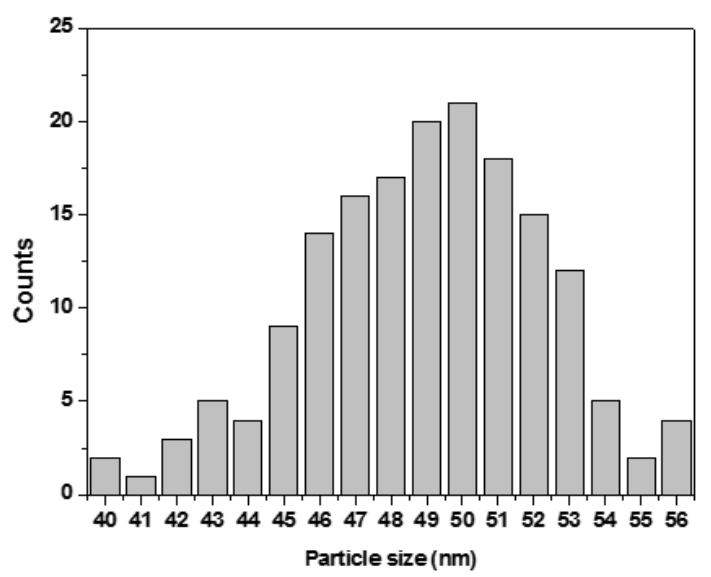

(d)

Figure 2. (a) Selected area electron diffraction (SAED) pattern (40 cm camera length), (b) high-resolution transmission electron microscopy (HRTEM) image, (c) TEM image, and (d) size distribution histogram of $\mathrm{Cu}_{0.04} \mathrm{Zn}_{0.96} \mathrm{O}$ NPs.

Furthermore, a shift in the peak position was detected as the copper concentration increased (Figure $1 b$ ). This shift toward a higher $2 \theta$ was easily distinguished for $\mathrm{Cu}_{0.04} \mathrm{Zn}_{0.96} \mathrm{O}$ NPs, suggesting that the substitution of $\mathrm{Zn}$ by $\mathrm{Cu}$ in the $\mathrm{ZnO}$ wurtzite structure was successful. This may have been due to the small differences between the $\mathrm{Zn}$ and $\mathrm{Cu}$ ionic radii and their similar electronegativities [37]. Indeed, $\mathrm{Cu}^{2+}$ and $\mathrm{Zn}^{2+}$ ions have electronegativity values of 1.91 and 1.65 [38], and ionic radii of $0.73 \AA$ and $0.74 \AA$, respectively [39]. The morphology of the $\mathrm{Cu}_{0.04} \mathrm{Zn}_{0.96} \mathrm{O}$ NPs was studied using TEM. As shown in Figure $2 \mathrm{c}, \mathrm{d}$, the sample consisted of triangular NPs with a quite narrow size distribution in the range of 40-56 nm [40].

The average crystallite size and strain of the $\mathrm{Cu}_{x} \mathrm{Zn}_{1-x} \mathrm{O}$ NPs were extracted by fitting the Halder-Wagner $(\mathrm{H}-\mathrm{W})$ plots, as shown in Figure $3 \mathrm{a}, \mathrm{b}$. The obtained average crystallite size, lattice parameters, dislocation density, and strain rate for all samples are given in Table 1 . As can be seen, the average size increased with the $\mathrm{Cu}$ concentration, which proved that the incorporation of $\mathrm{Cu}^{2+}$ in the host $\mathrm{ZnO}$ lattice enhanced the growth rate of NPs [41]. It also induced a slight decrease in the lattice parameters due to the small difference in the ionic radius between $\mathrm{Zn}$ and $\mathrm{Cu}[21]$. 


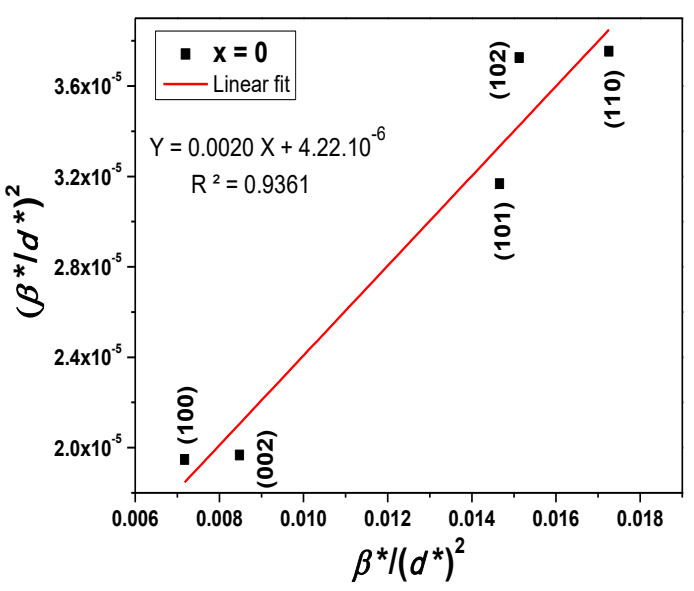

(a)

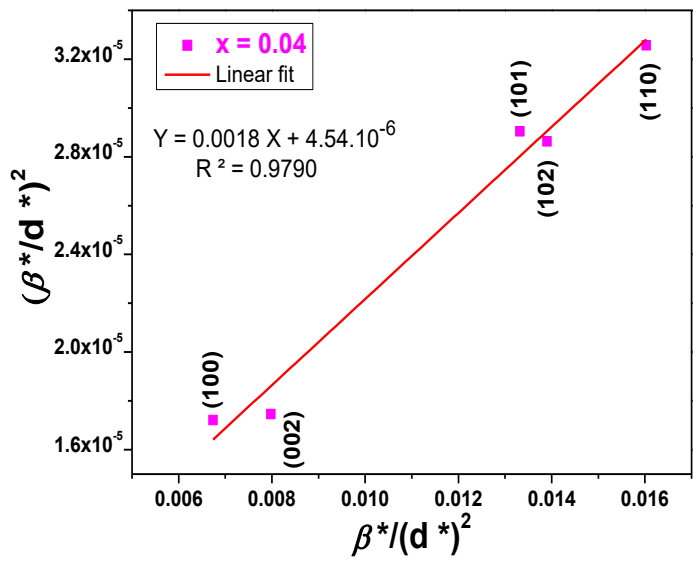

(b)

Figure 3. Halder-Wagner plots of $\mathrm{Cu}_{x} \mathrm{Zn}_{1-x} \mathrm{O}$ NPs $(x=0$ and 0.04$)$.

Table 1. Data for the value of the average crystallite size, lattice parameters ( $a$ and $c)$, strain, and dislocation density $(\delta)$ of $\mathrm{Cu}_{x} \mathrm{Zn}_{1-x} \mathrm{O}$ NPs.

\begin{tabular}{cccccc}
\hline NPs & \multicolumn{2}{c}{ Lattice Constants $(\mathbf{n m})$} & Strain & $\begin{array}{c}\delta \mathbf{( 1 0}^{-4} \mathbf{)} \\
\left(\mathbf{n m} \mathbf{- n}^{-\mathbf{n}}\right.\end{array}$ & $\begin{array}{c}\text { Particle Size } \\
(\mathbf{n m})\end{array}$ \\
\hline $\mathrm{anO}$ & 0.2862 & 0.4957 & 0.1 & 3.95 & 50.3 \\
$\mathrm{Cu}_{0.01} \mathrm{Zn}_{0.99} \mathrm{O}$ & 0.2861 & 0.4956 & 0.09 & 3.92 & 50.5 \\
$\mathrm{Cu}_{0.02} \mathrm{Zn}_{0.98} \mathrm{O}$ & 0.2860 & 0.4955 & 0.08 & 3.84 & 51 \\
$\mathrm{Cu}_{0.03} \mathrm{Zn}_{0.97} \mathrm{O}$ & 0.2859 & 0.4953 & 0.08 & 3.81 & 51.2 \\
$\mathrm{Cu}_{0.04} \mathrm{Zn}_{0.96} \mathrm{O}$ & 0.2856 & 0.4947 & 0.08 & 3.11 & 56.7 \\
\hline
\end{tabular}

FTIR was used to gain information about the chemical bonding and to identify the elemental constituents of our samples [42]. The FTIR spectra for undoped and Cu-doped $\mathrm{ZnO}$ NPs are presented in Figure 4. The broad absorption band at $3434 \mathrm{~cm}^{-1}$ was assigned to the stretching vibration of hydroxyl groups. These vibrations came from water molecules absorbed onto the $\mathrm{Cu}_{x} \mathrm{Zn}_{1-x} \mathrm{O}$ NPs. The band at $1606 \mathrm{~cm}^{-1}$ was assigned to the bending mode of $\mathrm{H}-\mathrm{O}-\mathrm{H}$ [43]. The series of peaks at 1423, 2856, and $2922 \mathrm{~cm}^{-1}$ were due to the $\mathrm{C}-\mathrm{H}$ bending and stretching vibrations of alkane chains (most likely from the zinc acetate precursor), and the peak around $867 \mathrm{~cm}^{-1}$ corresponded to the $\mathrm{C}-\mathrm{H}$ bending vibration $[44,45]$. The peaks at about $2351 \mathrm{~cm}^{-1}$ were due to $\mathrm{CO}_{2}$ molecules present in the air [46]. The intense absorption band at about $450 \mathrm{~cm}^{-1}$ and relatively weak absorption peak at $621 \mathrm{~cm}^{-1}$ in the FTIR spectra corresponded to the characteristic stretching vibrations of $\mathrm{Zn}-\mathrm{O}$ and confirmed the formation of $\mathrm{ZnO}$ [47]. As the copper content increased in the $\mathrm{ZnO}$ lattice, its structure changed and presumably led to changes in the shape of low wavenumber features. The stretching frequency at $621 \mathrm{~cm}^{-1}$ for undoped $\mathrm{ZnO}$ was noticeably shifted to a higher frequency up to $696 \mathrm{~cm}^{-1}$ for $x=0.04$. This agrees with the fact that copper atoms are lighter than $\mathrm{Zn}$ atoms, resulting in an upward shift of the fundamental transverse optical phonon mode [19].

Raman spectroscopy is a powerful diagnostic tool that is used to obtain information about the crystallization, structural disorder, and defects in the micro- and nanostructures [48]. The Raman spectra of the $\mathrm{Cu}_{x} \mathrm{Zn}_{1-x} \mathrm{O}$ NPs are shown in Figure 5. Peaks located at about 101,437 , and $584 \mathrm{~cm}^{-1}$ were assigned to the $\mathrm{E}_{2 \mathrm{~L}}, \mathrm{E}_{2 \mathrm{H}}$, and $\mathrm{A}_{1}$ longitudinal optical (LO) phonons of hexagonal $\mathrm{ZnO}$. The Raman peak positioned at about $203 \mathrm{~cm}^{-1}$ corresponded to the $2 \mathrm{E}_{2 \mathrm{~L}}$ second-order scattering. Additionally, the other Raman peak at about $333 \mathrm{~cm}^{-1}$ was attributed to the $\mathrm{E}_{2 \mathrm{H}}-\mathrm{E}_{2 \mathrm{~L}}$ multiphonon scattering [49-51]. The $\mathrm{E}_{2 \mathrm{H}}$ mode is mainly caused by the vibration of oxygen atoms, which are sensitive to internal stress [52]. It is characteristic of the hexagonal wurtzite structure of $\mathrm{ZnO}$ nanostructures [53]. The $\mathrm{E}_{2 \mathrm{H}}$ Raman line broadens with increasing $\mathrm{Cu}$ content [52,54]. Doping introduces chemical dis- 
order (to which Raman spectroscopy is sensitive) and can also introduce lattice defects and disorder. Defect-induced Raman modes manifest in defective crystals because the Raman selection rules are relaxed [55]. As the copper concentration increased, the $\mathrm{A}_{1}(\mathrm{LO})$ peak broadened and shifted about $13 \mathrm{~cm}^{-1}$ toward lower wavenumbers. This result is consistent with already reported work [56]. The shift and broadening of the $A_{1}$ (LO) phonon peak were assigned to the scattering contributions of the $A_{1}(\mathrm{LO})$ branch outside the Brillouin zone center [57]. Light scattering by the $\mathrm{A}_{1}(\mathrm{LO})$ phonon is commonly attributed to oxygen vacancies or zinc interstitials in $\mathrm{ZnO}$ [58].

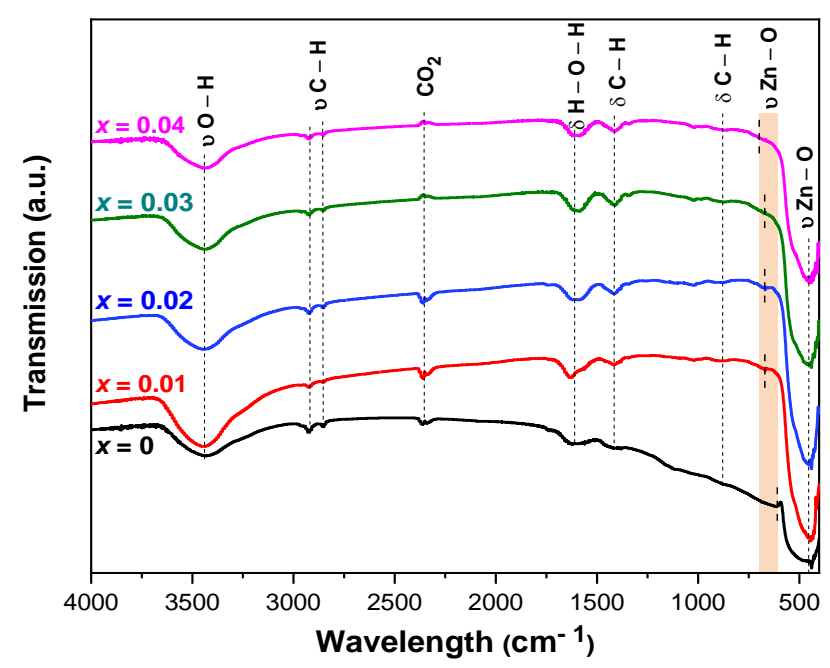

Figure 4. Fourier-transform infrared (FTIR) spectra of $\mathrm{Cu}_{x} \mathrm{Zn}_{1-x} \mathrm{O}$ NPs $(x=0,0.01,0.02,0.03$, and 0.04).

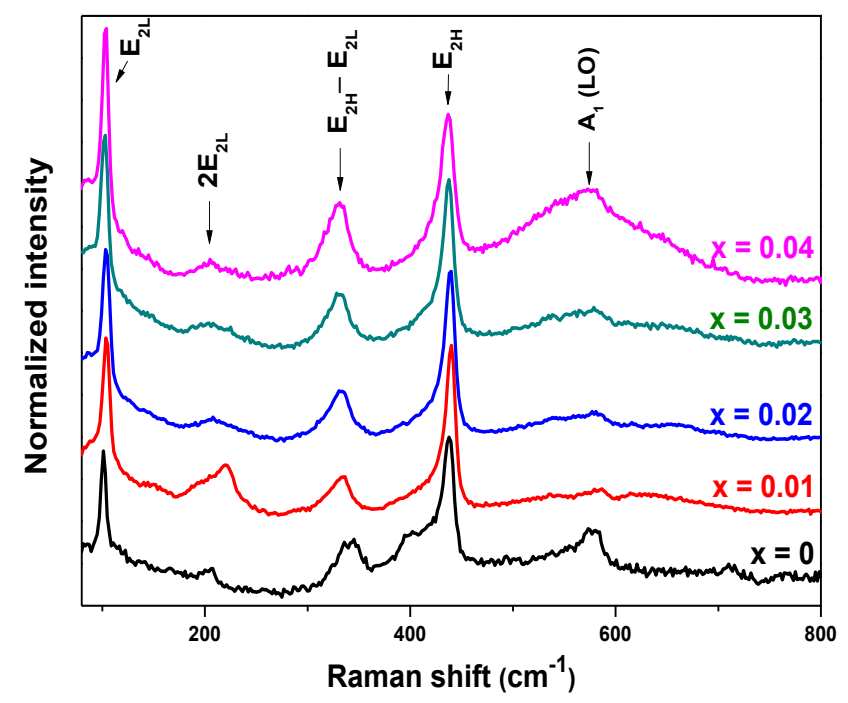

Figure 5. Raman spectra of $\mathrm{Cu}_{x} \mathrm{Zn}_{1-x} \mathrm{O}$ NPs $(x=0,0.01,0.02,0.03$, and 0.04). LO: longitudinal optical.

The zeta potential measurements of the $\mathrm{Cu}_{x} \mathrm{Zn}_{1-x} \mathrm{O}$ NPs $(x=0,0.01,0.02,0.03$, and $0.04)$ are shown in Figure 6. The incorporation of $\mathrm{Cu}$ into the $\mathrm{ZnO}$ increased the electrical charge of the NPs and caused a shift of the IEP toward higher values. $\mathrm{ZnO}$ has an isoelectric point around $\mathrm{pH} 9$, which increased to 9.9 for $\mathrm{Cu}_{0.04} \mathrm{Zn}_{0.96} \mathrm{O}$ NPs, suggesting that the surface-charging behavior was changed as the $\mathrm{Cu}$ content increased. This proved that the incorporation of $\mathrm{Cu}$ enhanced the adsorption of hydroxyl on the NPs' surfaces and hence increased the affinity to protons, which resulted in the increase of the IEP [59]. Above the IEP, the NPs carried a net negative charge and thus a high affinity for positively charged species. 


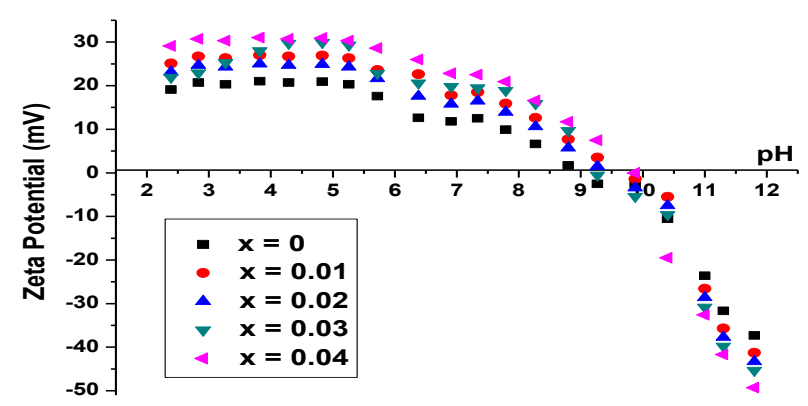

Figure 6. Zeta potential curves of $\mathrm{Cu}_{x} \mathrm{Zn}_{1-x} \mathrm{O}$ NPs $(x=0,0.01,0.02,0.03$, and 0.04$)$ in $10^{-2} \mathrm{M} \mathrm{NaCl}$.

\subsection{Electrochemical Characterization of the $\mathrm{Cu}_{x} \mathrm{Zn}_{1-x} \mathrm{O} / \mathrm{ITO}$ Modified Electrodes}

The cyclic voltammograms of doped and undoped $\mathrm{ZnO}$ samples in $0.1 \mathrm{M} \mathrm{NaOH}$ are shown in Figure 7. At the $\mathrm{ZnO} / \mathrm{ITO}$ electrode, a low oxidation current existed. Doped $\mathrm{ZnO}$ samples showed an important $\mathrm{Cu}$ (II)-Cu(III) redox peak, which enhanced and shifted toward a lower potential as the $\mathrm{Cu}$ content increased. These enhanced peak current and potential shift were attributed to the improved conductivity and electrocatalytic properties due to the copper doping [60]. Interestingly, the electrocatalytic activity of the $\mathrm{Cu}_{0.04} \mathrm{Zn}_{0.96} \mathrm{O} / \mathrm{ITO}$ electrode was noticeably different from the others. It showed a couple of strong and well-defined redox peaks. The increased current density occurred because of the charge carriers approaching the conduction band of $\mathrm{ZnO}$, which could be involved in the charge transfer at the metal oxide/electrolyte interface [61]. From this observation, the increase in dopant concentration provided a higher electrical conductivity, faster electron transfer kinetics, and excellent electroactive surface area, thereby improving the electrochemical response [62].

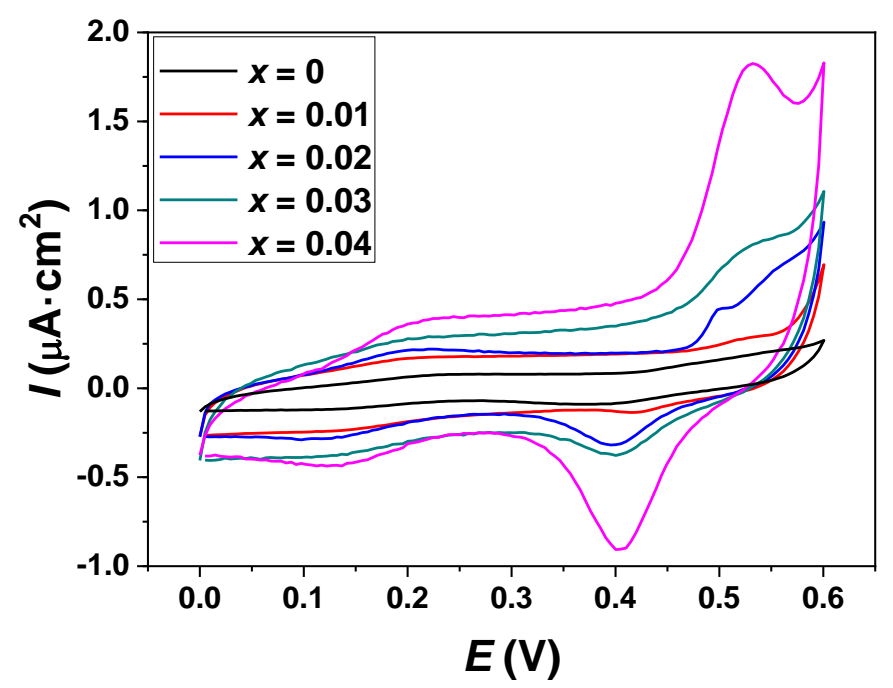

Figure 7. Cyclic voltammograms of the $\mathrm{Cu}_{x} \mathrm{Zn}_{1-x} \mathrm{O} / \mathrm{ITO}$ modified electrodes that were obtained in the absence of glucose at a scan rate of $50 \mathrm{mV} \cdot \mathrm{s}^{-1}$.

Electrochemical impedance spectroscopy (EIS) is a particularly important tool for investigating the interfacial properties of the modified electrodes. This method has recently attracted extensive attention in the field of analytical sciences since it can provide complementary information about the reaction dynamics and the membrane/solution structure. Figure 8 shows the Nyquist plots of the EIS for $\mathrm{Cu}_{x} \mathrm{Zn}_{1-x} \mathrm{O} / \mathrm{ITO}(x=0,0.01,0.02$, 0.03 , and 0.04 ) electrodes in $0.1 \mathrm{M} \mathrm{NaOH}$. We observed that the semicircle diameter of the sensors decreased dramatically with increasing $x$ values. This decrease was attributed to the variation of the electric parameters of the membrane with increasing $\mathrm{Cu}$ doping content. 


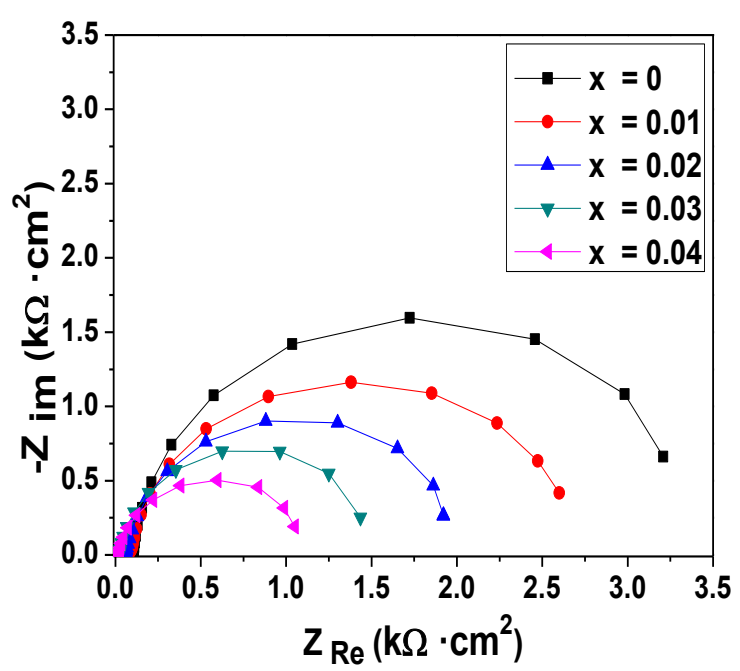

Figure 8. Nyquist plots for different electrodes in $0.1 \mathrm{M} \mathrm{NaOH}$ that were obtained in the absence of glucose.

The EIS data were fitted using ZView software (Southern Pines, NC, USA) to determine these parameters. An example of the Nyquist and Bode diagrams' fits of the $\mathrm{Cu}_{0.04} \mathrm{Zn}_{0.96} \mathrm{O} / \mathrm{ITO}$ electrode is presented in the Supplementary Information (Figure S2). This figure shows that the phase plot presented a large phase angle maximum, which proved that the two-phase angle maxima merged toward each other. Hence, the Nyquist plots were modeled as an overlapping of two semicircles. The equivalent circuit that best fit the Nyquist plots with a low total error is presented in Figure 9. It was composed of the electrolyte resistance $\left(R_{\mathrm{s}}\right)$ in series with two parallel combinations of a resistance and a constant phase element. The first one refers to the high-frequency loop. The electrochemical phenomenon occurring at the ITO/electrolyte interface was modeled using the charge transfer resistance $\left(R_{\mathrm{ct}}\right)$ and the constant phase element $\mathrm{CPE}_{1}$. The second loop $\left(R_{\mathrm{ad}}, \mathrm{CPE}_{2}\right)$ was introduced to describe the adsorption on the electrode surface in the low-frequency region. The CPE element is a non-ideal capacitor that can be expressed using the following equation [63]: $\mathrm{CPE}=1 / Q(j \omega)^{n}$, where $Q$ is a frequency-independent term that refers to the homogeneity, roughness, and surface porosity, $j$ is an imaginary number $(j=\sqrt{-1}), \omega$ is the angular frequency $(\omega=2 \pi f)$, and $0<n<1$. CPE becomes more capacitive when the value of $n$ tends to 1 [64]. The fitted values, along with the total error $\left(\chi^{2}\right)$, are given in Table 2. When increasing the $\mathrm{Cu}$ doping, there was an increase in the CPE values, denoting the accumulation of charge at the electrode surface, which was accompanied by a gradual decrease in $R_{\mathrm{ct}}$ and $R_{\mathrm{ad}}$. The decrease in $R_{\mathrm{ct}}$ revealed the enhancement of the electrical conductivity. The dramatic decrease in $R_{\mathrm{ad}}$ resulted from the improved adsorption ability with increasing the $\mathrm{Cu}$ doping because it mainly took place at the $\mathrm{Cu}$ electrocatalytic active sites. Hence, $\mathrm{Cu}$ doping provided many active sites and high surface energies. The lowest resistances were obtained at the $\mathrm{Cu}_{0.04} \mathrm{Zn}_{0.96} \mathrm{O} / \mathrm{ITO}$ electrode. This is in agreement with the cyclic voltammetry results and confirms that $\mathrm{Cu}_{0.04} \mathrm{Zn}_{0.96} \mathrm{O} / \mathrm{ITO}$ electrodes are good candidates for the electrochemical sensing of glucose.

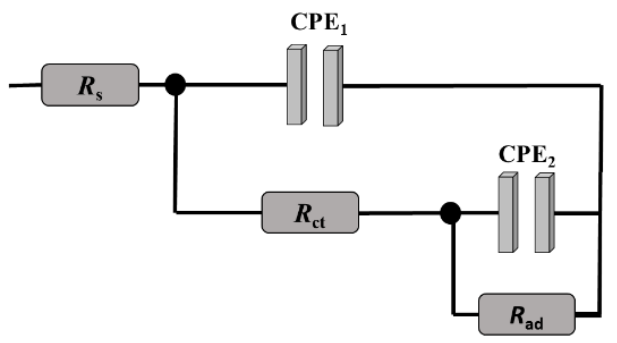

Figure 9. Equivalent electrical circuit that was used to model the impedance spectra. 
Table 2. Electrical parameter values that were obtained from fitting the impedance spectra of different electrodes.

\begin{tabular}{|c|c|c|c|c|c|c|c|c|}
\hline Electrodes & $\begin{array}{l}R_{\mathrm{S}}\left(10^{-3}\right) \\
\left(\mathrm{k} \Omega \cdot \mathrm{cm}^{2}\right)\end{array}$ & $\begin{array}{l}\mathrm{CPE}_{1} \\
(\mu \mathrm{F})\end{array}$ & $n_{1}$ & $\begin{array}{l}R_{\mathrm{ct}}\left(10^{-3}\right) \\
\left(\mathrm{k} \Omega \cdot \mathrm{cm}^{2}\right)\end{array}$ & $\begin{array}{l}\mathrm{CPE}_{2} \\
(\mu \mathrm{F})\end{array}$ & $n_{2}$ & $\begin{array}{c}R_{\mathrm{ad}}\left(10^{-3}\right) \\
\left(\mathrm{k} \Omega \cdot \mathrm{cm}^{2}\right)\end{array}$ & $\chi^{2}\left(10^{-4}\right)$ \\
\hline $\mathrm{ZnO}$ & 66.4 & $7.2 \pm 0.1$ & 0.98 & $706.9 \pm 0.2$ & $2.6 \pm 0.1$ & 0.98 & $\begin{array}{c}2520.3 \pm \\
0.2\end{array}$ & 5.56 \\
\hline $\mathrm{Cu}_{0.01} \mathrm{Zn}_{0.99} \mathrm{O}$ & 64.8 & $8.6 \pm 0.2$ & 0.99 & $636.2 \pm 0.2$ & $6.4 \pm 0.1$ & 0.99 & $\begin{array}{c}2028.6 \pm \\
0.1\end{array}$ & 7.26 \\
\hline $\mathrm{Cu}_{0.02} \mathrm{Zn}_{0.98} \mathrm{O}$ & 47.9 & $19.1 \pm 0.1$ & 0.98 & $569.3 \pm 0.1$ & $9.9 \pm 0.1$ & 0.97 & $\begin{array}{c}1327.8 \pm \\
0.1\end{array}$ & 5.12 \\
\hline $\mathrm{Cu}_{0.03} \mathrm{Zn}_{0.97} \mathrm{O}$ & 25.2 & $34.5 \pm 0.1$ & 0.97 & $542.6 \pm 0.1$ & $13.9 \pm 0.1$ & 0.97 & $990.3 \pm 0.2$ & 2.89 \\
\hline $\mathrm{Cu}_{0.04} \mathrm{Zn}_{0.96} \mathrm{O}$ & 17.5 & $35.6 \pm 0.2$ & 0.99 & $302.9 \pm 0.1$ & $15.7 \pm 0.2$ & 0.99 & $810.5 \pm 0.1$ & 3.74 \\
\hline
\end{tabular}

\subsection{Electrochemical Study of Glucose Sensing at the $\mathrm{Cu}_{0.04} \mathrm{Zn}_{0.96} \mathrm{O} / \mathrm{ITO}$ Electrode}

\subsubsection{Cyclic Voltammetry (CV)}

$\mathrm{CV}$ was used to study the effect of the glucose concentration on the electrocatalytic performance of the $\mathrm{Cu}_{0.04} \mathrm{Zn}_{0.96} \mathrm{O} / \mathrm{ITO}$ electrode in $0.1 \mathrm{M} \mathrm{NaOH}$. Figure 10 represents the cyclic voltammograms of the $\mathrm{Cu}_{0.04} \mathrm{Zn}_{0.96} \mathrm{O} / \mathrm{ITO}$ electrode for various concentrations of glucose at a scan rate of $50 \mathrm{mV} \cdot \mathrm{s}^{-1}$. A well-defined pair of redox peaks was observed at $0.53 \mathrm{~V}$ and $0.40 \mathrm{~V}$. These peaks were attributed to the $\mathrm{Cu}(\mathrm{II}) / \mathrm{Cu}(\mathrm{III})$ redox couple in the alkaline medium. However, the anodic and cathodic peak currents increased with increasing glucose concentration, proving that glucose was oxidized by the $\mathrm{Cu}_{0.04} \mathrm{Zn}_{0.96} \mathrm{O} / \mathrm{ITO}$ electrode. The cyclic voltammograms of $\mathrm{Cu}_{0.05} \mathrm{Zn}_{0.95} \mathrm{O}$ NPs in the absence and presence of glucose are presented in the Supplementary Information (Figure S3). According to the cyclic voltammograms, the $\mathrm{Cu}_{0.04} \mathrm{Zn}_{0.96} \mathrm{O}$ NPs were more promising for detecting glucose due to the presence of sharper redox peaks than the $\mathrm{Cu}_{0.05} \mathrm{Zn}_{0.95} \mathrm{O}$ NPs. It seems that the appearance of the secondary $\mathrm{CuO}$ phase with increasing $\mathrm{Cu}$ doping up to $x=0.05$ affected the NPs' ability to detect glucose.

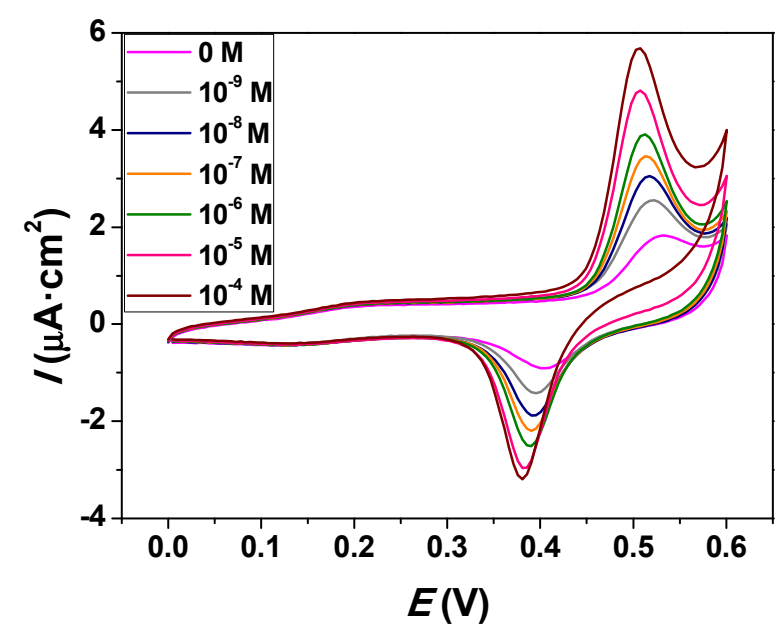

Figure 10. Cyclic voltammograms of the $\mathrm{Cu}_{0.04} \mathrm{Zn}_{0.96} \mathrm{O} / \mathrm{ITO}$ electrode in $0.1 \mathrm{M} \mathrm{NaOH}$ containing various concentrations of glucose.

During the electrocatalytic oxidation of glucose, $\mathrm{Cu}(0)$ was first oxidized into $\mathrm{Cu}(\mathrm{II})$ (reaction 1 below). $\mathrm{Cu}$ (II) species were then oxidized into $\mathrm{Cu}(\mathrm{III})$ (reaction 2). Then, the oxidation of glucose was mainly based on the $\mathrm{Cu}(\mathrm{OH})_{2} / \mathrm{CuOOH}$ redox couple (reaction 3). Therefore, the loss of electrons at the surface to produce the $\mathrm{Cu}$ (III) species instantly activated the electrode and acted as a strong oxidant, with empty d-orbitals being available to adsorb glucose. The glucose electro-oxidation process might have consisted of the adsorption of a glucose molecule on the electrode surface via dehydrogenation of the glucose molecule at the hemiacetalic carbon 1 atom $\left(C_{1}\right)$ to form an adsorbed radical intermediate 
(Figure 11), which in turn reacted quickly with hydroxyl anions in the electrolyte to form gluconolactone (Figure 12). Finally, the resulting gluconolactone spontaneously converted into gluconic acid via hydrolysis (reaction 4 ). The electrocatalytic oxidation reactions can be written as follows [35]:

$$
\begin{gathered}
\mathrm{Cu}+2 \mathrm{OH}^{-} \rightarrow \mathrm{Cu}(\mathrm{OH})_{2}+2 e^{-}, \\
\mathrm{Cu}(\mathrm{OH})_{2}+\mathrm{OH}^{-} \rightarrow \mathrm{CuOOH}+\mathrm{H}_{2} \mathrm{O}+e^{-}, \\
\mathrm{CuOOH}+\text { glucose } \rightarrow \mathrm{Cu}(\mathrm{OH})_{2}+\text { gluconolactone, } \\
\text { gluconolactone } \stackrel{\text { hydrolysis }}{\rightarrow} \text { gluconic acid. }
\end{gathered}
$$

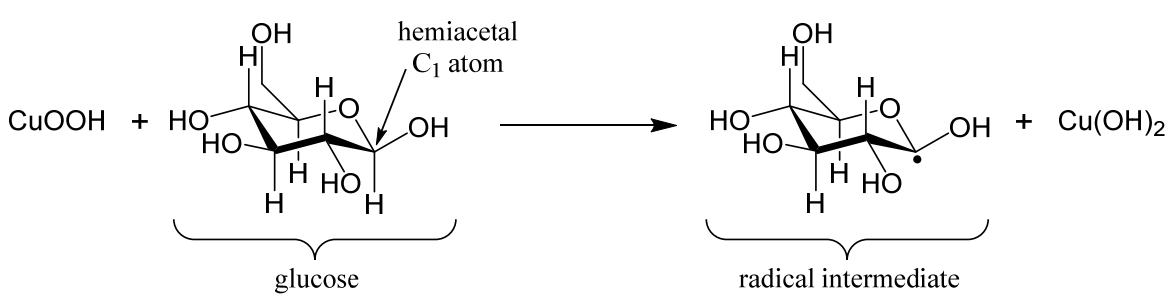

Figure 11. Dehydrogenation of the glucose molecule at the hemiacetalic carbon 1 atom (C1) to form an adsorbed radical intermediate.
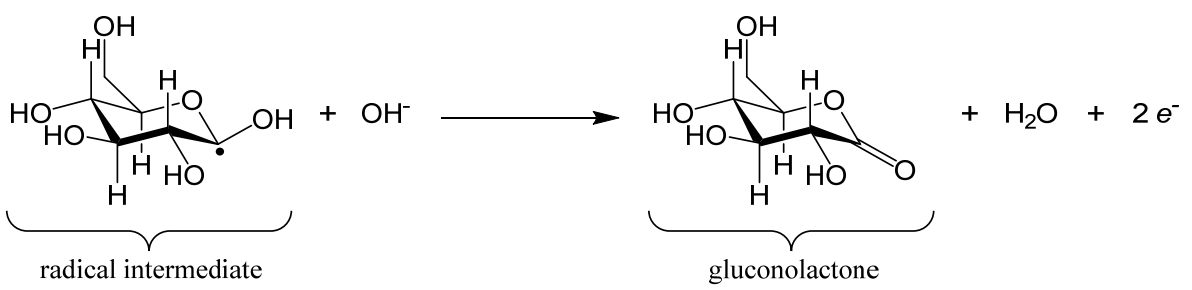

Figure 12. The radical intermediate reacted quickly with hydroxyl anions in the electrolyte to form gluconolactone.

\subsubsection{Electrochemical Impedance Spectroscopy}

Nyquist plots for the $\mathrm{Cu}_{0.04} \mathrm{Zn}_{0.96} \mathrm{O} / \mathrm{ITO}$ electrode in $0.1 \mathrm{M} \mathrm{NaOH}$ solution for different glucose concentrations, ranging from $1 \mathrm{nM}$ to $100 \mu \mathrm{M}$, are shown in Figure 13. They consisted of the overlapping of two semicircles whose diameters decreased with increasing glucose concentrations. This decrease proved the good interaction between glucose and the sensing membrane. The electrochemical properties of the membrane were quantified by fitting the impedance plots using the circuit already presented in Figure 9. The values of the electrical parameters that were obtained by fitting the data are given in Table 3 . The solution resistance $\left(R_{\mathrm{S}}\right)$ was almost constant for all the concentrations of glucose. The CPE values were not affected by the increase in glucose concentration, whereas $R_{\mathrm{ct}}$ and $R_{\text {ad }}$ decreased significantly for increasing glucose concentrations. On the one hand, the decrease in $R_{\mathrm{ct}}$ revealed an enhancement in the electrical conductivity that assisted the needed conductive pathways by providing a high electron transfer between the sensing membrane and the glucose. On the other hand, the decrease in $R_{\text {ad }}$ was due to the large surface area, which in turn improved the availability of metallic centers that facilitated the interaction with glucose and led to their accessibility to an active site. Thereby, this result revealed the high electrocatalytic activity of the $\mathrm{Cu}_{0.04} \mathrm{Zn}_{0.96} \mathrm{O} / \mathrm{ITO}$ electrode toward glucose oxidation as it improved the conversion of glucose into gluconolactone via the oxidation of $\mathrm{Cu}(\mathrm{OH})_{2}$ to $\mathrm{CuOOH}$. 


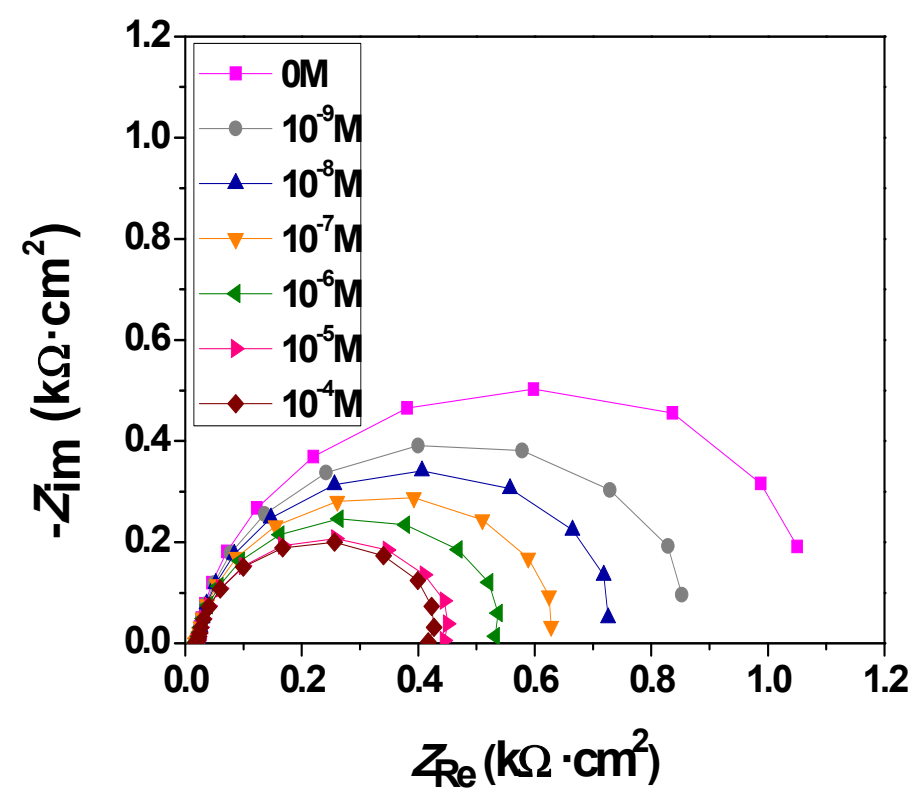

Figure 13. Nyquist plots for the $\mathrm{Cu}_{0.04} \mathrm{Zn}_{0.96} \mathrm{O} / \mathrm{ITO}$ electrode in $0.1 \mathrm{M} \mathrm{NaOH}$ solution for $0-10^{-4} \mathrm{M}$ glucose concentration ranges.

Table 3. Fitting data of the $\mathrm{Cu}_{0.04} \mathrm{Zn}_{0.96} \mathrm{O} / \mathrm{ITO}$ sensing electrode for different concentrations of glucose.

\begin{tabular}{|c|c|c|c|c|c|c|c|c|}
\hline $\begin{array}{c}\text { Glucose } \\
\text { Concentration (M) }\end{array}$ & $\begin{array}{l}R_{\mathrm{s}}\left(10^{-3}\right) \\
\left(\mathrm{k} \Omega \cdot \mathrm{cm}^{2}\right)\end{array}$ & $\begin{array}{l}\mathrm{CPE}_{1} \\
(\mu \mathrm{F})\end{array}$ & $n_{1}$ & $\begin{array}{l}R_{\mathrm{ct}}\left(10^{-3}\right) \\
\left(\mathrm{k} \Omega \cdot \mathrm{cm}^{2}\right)\end{array}$ & $\begin{array}{l}\mathrm{CPE}_{2} \\
(\mu \mathrm{F})\end{array}$ & $n_{2}$ & $\begin{array}{l}R_{\mathrm{ad}}\left(10^{-3}\right) \\
\left(\mathrm{k} \Omega \cdot \mathrm{cm}^{2}\right)\end{array}$ & $\chi^{2}\left(10^{-4}\right)$ \\
\hline 0 & 17.5 & $35.6 \pm 0.2$ & 0.99 & $302.9 \pm 0.1$ & $15.7 \pm 0.2$ & 0.99 & $810.5 \pm 0.1$ & 3.74 \\
\hline $10^{-9}$ & 17.4 & $36.6 \pm 0.5$ & 0.98 & $243.2 \pm 0.1$ & $16.1 \pm 0.2$ & 0.99 & $607.2 \pm 0.1$ & 5.62 \\
\hline $10^{-8}$ & 17.2 & $36.4 \pm 0.6$ & 0.99 & $192.2 \pm 0.1$ & $15.8 \pm 0.1$ & 0.99 & $508.4 \pm 0.2$ & 2.35 \\
\hline $10^{-7}$ & 17.5 & $36.2 \pm 0.2$ & 0.97 & $151.2 \pm 0.2$ & $15.6 \pm 0.3$ & 0.98 & $450.7 \pm 0.2$ & 6.24 \\
\hline $10^{-6}$ & 17.0 & $36.1 \pm 0.1$ & 0.98 & $131.8 \pm 0.1$ & $15.2 \pm 0.1$ & 0.99 & $390.3 \pm 0.1$ & 6.45 \\
\hline $10^{-5}$ & 16.8 & $35.9 \pm 0.3$ & 0.97 & $102.1 \pm 0.2$ & $16.2 \pm 0.2$ & 0.98 & $342.5 \pm 0.1$ & 3.59 \\
\hline $10^{-4}$ & 16.7 & $36.3 \pm 0.5$ & 0.98 & $94.2 \pm 0.2$ & $16.2 \pm 0.1$ & 0.99 & $326.6 \pm 0.1$ & 6.12 \\
\hline
\end{tabular}

\subsubsection{Differential Pulse Voltammetry (DPV) Detection of Glucose}

Figure $14 \mathrm{a}$ shows the DPV analysis of the $\mathrm{Cu}_{0.04} \mathrm{Zn}_{0.96} \mathrm{O} / \mathrm{ITO}$ electrode for different glucose concentrations. Well-defined oxidation peaks of glucose were observed. The calibration plot (Figure 14b) shows that the DPV peak current was proportional to the logarithmic concentration of glucose in the $1 \mathrm{nM}$ to $100 \mu \mathrm{M}$ range. The equation of the calibration plot was $I_{\mathrm{p}}(\mu \mathrm{A})=-1.75 \mathrm{X}+29.57\left(R^{2}=0.9897\right)$. The limit of detection (LOD) was estimated to be $0.7 \mathrm{nM}$ based on LOD $=3 \times S D / S$, where $S D$ is the standard deviation of the response and $S$ is the slope of the calibration curve [65]. A comparison of the analytical performance of the $\mathrm{Cu}_{0.04} \mathrm{Zn}_{0.96} \mathrm{O} / \mathrm{ITO}$ electrode with other electrochemical sensors for glucose detection is shown in Table 4 . The low limit of detection was associated with the high specific surface ratio of the NPs and the improved interaction between the modified electrode surface and analytes. Therefore, our $\mathrm{Cu}_{0.04} \mathrm{Zn}_{0.96} \mathrm{O} / \mathrm{ITO}$-modified electrode showed good analytical properties that were suitable for the quantification of glucose down to nanomolar concentrations. 

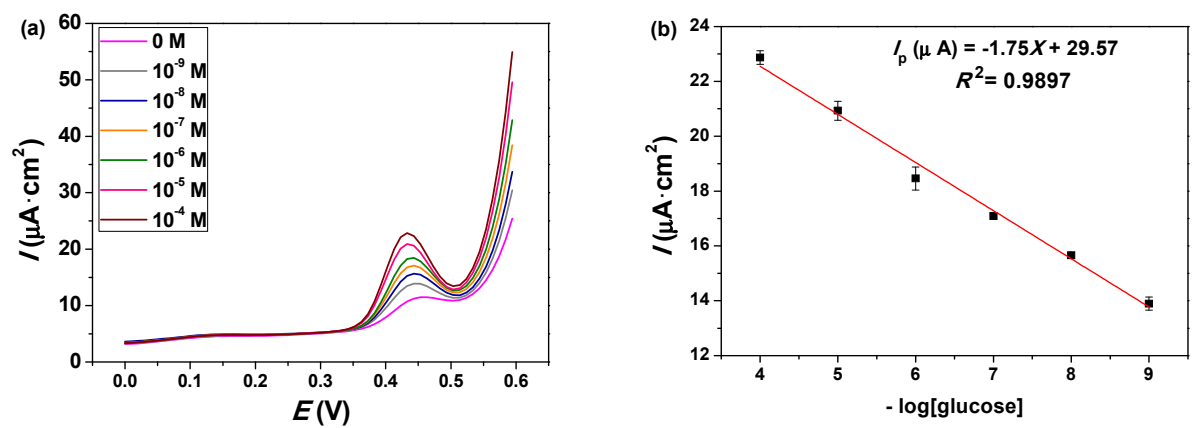

Figure 14. (a) Differential pulse voltammograms of the $\mathrm{Cu}_{0.04} \mathrm{Zn}_{0.96} \mathrm{O} / \mathrm{ITO}$ electrode for different glucose concentrations. (b) Linear calibration curve of the peak currents vs. the logarithmic glucose concentration.

Table 4. Comparison of the sensing performance found in this work with similar non-enzymatic glucose sensors.

\begin{tabular}{|c|c|c|c|c|}
\hline Electrode Material & Linear Range $(\mu \mathrm{M})$ & Detection Limit $(\mu \mathrm{M})$ & Analytical Technique & Reference \\
\hline $\mathrm{Ni}(\mathrm{II})-\mathrm{CP} / \mathrm{C}_{60}$ & 10 to $3 \times 10^{3}$ & 4.3 & Amp & {$[66]$} \\
\hline Mucilage-AgNPs/GC & 10 to $2.2 \times 10^{3}$ & 10 & SWV & [67] \\
\hline $\mathrm{Net}-\mathrm{Co}_{3}\left(\mathrm{PO}_{4}\right)_{2} / \mathrm{NG}$ & 0.05 to $2 \times 10^{3}$ & 1 & Amp & [68] \\
\hline $\mathrm{ZnO} / \mathrm{CeO}_{2}$ whisker & 0.5 to 300 & 0.22 & DPV & [69] \\
\hline $\mathrm{Au} @ \mathrm{Cu}_{2} \mathrm{O}$ & 50 to $2 \times 10^{3}$ & 18 & $\mathrm{CV}$ & [70] \\
\hline HLTH/NF & 15 to $8 \times 10^{3}$ & 1.49 & Amp & [71] \\
\hline $\mathrm{Au}-\mathrm{TiO}_{2} \mathrm{NTs}$ & 50 to $3 \times 10^{3}$ & 50 & $\mathrm{CV}$ & [72] \\
\hline $\mathrm{CuO}$ nanodisks & 2 to $2.5 \times 10^{3}$ & 0.2 & Amp & [73] \\
\hline $\mathrm{Cu}_{0.04} \mathrm{Zn}_{0.96} \mathrm{O}$ & $10^{-3}$ to 100 & $7 \times 10^{-4}$ & DPV & This work \\
\hline
\end{tabular}

Ni(II)-CP/C60: Ni(II)-coordination polymer and fullerene (C60), Amp: amperometry, AgNPs: silver NPs, GC: glassy carbon, SWV: squarewave voltammetry, Net-Co $3\left(\mathrm{PO}_{4}\right)_{2} / \mathrm{NG}$ : networked cobaltous phosphate decorated with nitrogen-doped reduced graphene oxide, DPV: differential pulse voltammetry, $\mathrm{CeO}_{2}$ : cerium oxide, $\mathrm{Cu}_{2} \mathrm{O}$ : cuprous oxide, AuNPs: gold NPs, $\mathrm{HLTH} / \mathrm{NF}$ : hollow triple-layered hydroxide modified nickel foam, $\mathrm{Au}-\mathrm{TiO}_{2} \mathrm{NTs}$ : gold layers deposited onto $\mathrm{TiO}_{2}$ nanotubes, $\mathrm{CuO}$ : copper oxide.

\subsection{Interferences and Practical Application of $C u_{0.04} \mathrm{Zn}_{0.96} \mathrm{O} / \mathrm{ITO}$ Electrodes}

A challenge regarding non-enzymatic glucose sensors is the prevention of interfering reagents. We examined the specificity of the $\mathrm{Cu}_{0.04} \mathrm{Zn}_{0.96} \mathrm{O} / \mathrm{ITO}$ glucose sensor toward interfering species, such as ascorbic acid (AA), uric acid (UA), fructose, sucrose, maltose, and lactose. Figure 15 shows the DPV of the $\mathrm{Cu}_{0.04} \mathrm{Zn}_{0.96} \mathrm{O} / \mathrm{ITO}$ electrode in the presence of glucose and the above-mentioned species. The results indicated that the response of our electrode for these molecules was negligible compared to the response to glucose [74]. Therefore, the presence of these interfering species had no influence on the detection of glucose. The developed sensor based on $\mathrm{Cu}_{0.04} \mathrm{Zn}_{0.96} \mathrm{O}$ NPs was highly specific toward the sensing of glucose.

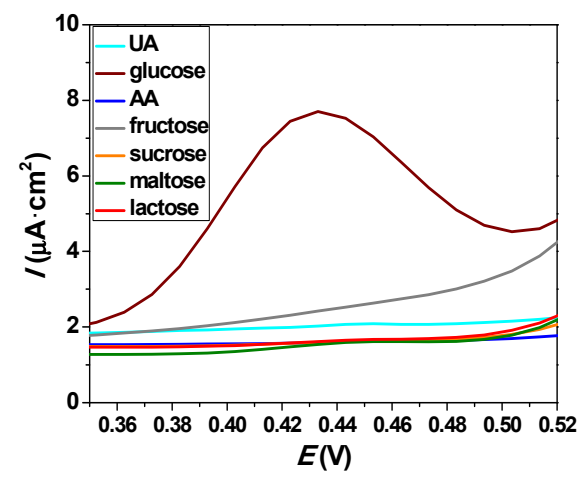

Figure 15. Differential pulse voltammetry of the $\mathrm{Cu}_{0.04} \mathrm{Zn}_{0.96} \mathrm{O} / \mathrm{ITO}$ electrode in the presence of a $10^{-4} \mathrm{M}$ concentration of uric acid (UA), glucose, ascorbic acid (AA), fructose, sucrose, maltose, and lactose in a $0.1 \mathrm{M} \mathrm{NaOH}$ solution. 


\subsection{Practical Applications}

The practical feasibility of the developed sensor electrode was confirmed by the detection of glucose in human blood serum samples. The concentration of glucose was measured via the addition of fresh serum that was diluted ten times into a $0.1 \mathrm{M} \mathrm{NaOH}$ solution. The recoveries were evaluated in the standard addition way by adding a glucose concentration to the resulting solution. Analytical recoveries of the added glucose into the human serum samples were between 80 and $99.6 \%$ (Table 5). These recoveries of glucose proved the potential of our $\mathrm{Cu}_{0.04} \mathrm{Zn}_{0.96} \mathrm{O} / \mathrm{ITO}$ electrode to be used in practical applications.

Table 5. Determination of glucose in human serum samples by the $\mathrm{Cu}_{0.04} \mathrm{Zn}_{0.96} \mathrm{O} / \mathrm{ITO}$ electrode.

\begin{tabular}{cccc}
\hline Sample & Added Concentration $(\boldsymbol{\mu M})$ & Found $(\boldsymbol{\mu M})$ & Recoveries $(\%)$ \\
\hline \multirow{3}{*}{ Human serum } & 0.05 & 0.04 & 80.0 \\
& 5 & 4.98 & 99.6 \\
& 500 & 497 & 99.4 \\
\hline
\end{tabular}

\section{Materials and Methods}

\subsection{Chemicals and Reagents}

Zinc acetate dihydrate $\left(\mathrm{Zn}\left(\mathrm{CH}_{3} \mathrm{COO}\right)_{2} \cdot 2 \mathrm{H}_{2} \mathrm{O}, 99.99 \%\right.$ purity), copper chloride dihydrate $\left(\mathrm{CuCl}_{2} \cdot 2 \mathrm{H}_{2} \mathrm{O}\right)$, polyvinyl alcohol Mowiol 4-88 (88\% hydrolysis/MW: $\left.31 \mathrm{kDa}\right)$, sodium hydroxide ( $\mathrm{NaOH}$ pellets, $\geq 97.0 \%$ ), methanol, $\mathrm{D}-(+)$-glucose, ascorbic acid (AA), uric acid (UA), fructose, sucrose, maltose, and lactose were purchased from Sigma-Aldrich (St. Louis, MO, USA). They were of analytical grade and used as received, without further purification. Distilled water was used for the preparation of all aqueous solutions.

\subsection{Synthesis of $\mathrm{C} u_{x} \mathrm{Zn} n_{1-x} \mathrm{O}$ NPs}

The $\mathrm{Cu}_{x} \mathrm{Zn}_{1-x} \mathrm{O}(x=0,0.01,0.02,0.03$, and 0.04$)$ NPs were synthesized using a simple and low-cost sol-gel method. Briefly, $2 \mathrm{~g}$ of zinc acetate was solubilized in $14 \mathrm{~mL}$ methanol under magnetic stirring at $25{ }^{\circ} \mathrm{C}$ for $2 \mathrm{~h}$. Copper was added according to the desired $[\mathrm{Cu}] /([\mathrm{Zn}]+[\mathrm{Cu}])$ ratio $(0,0.01,0.02,0.03$, and 0.04$)$ under magnetic stirring until complete dissolution of the precursors was achieved. Then, the suspensions were centrifuged at 1512 RCF (relative centrifugal force) for $20 \mathrm{~min}$ and washed with distilled water and methanol. The wet powders were then placed in an autoclave and dried at $45^{\circ} \mathrm{C}$ and $7.2 \mathrm{MPa}$ in the supercritical condition of ethyl alcohol (EtOH) for $2 \mathrm{~h}$ [75].

\subsection{Electrode Preparation}

The NPs were dispersed in distilled water and added to an aqueous polyvinyl alcohol (PVA) solution. The addition of PVA facilitated the dispersion of NPs in water and their immobilization on the substrate. The resulting PVA-Cu $\mathrm{Zn}_{1-x} \mathrm{O}$ suspensions were then kept under magnetic stirring for $10 \mathrm{~min}$. The obtained suspensions were spin-coated on indium-doped tin oxide (ITO) substrates. The spinning time was $30 \mathrm{~s}$ and the spinning rate was 56 RCF. Finally, the electrodes were dried in an oven at $120^{\circ} \mathrm{C}$ for $1 \mathrm{~h}$.

\subsection{Characterization of the $\mathrm{Cu}_{x} \mathrm{Zn}_{1-x} \mathrm{O}$ NPs}

The crystalline structure of the $\mathrm{Cu}_{x} \mathrm{Zn}_{1-x} \mathrm{O}(x=0,0.01,0.02,0.03$, and 0.04) NPs was studied using XRD with a Bruker AXS D8 Advance X-ray diffractometer (Billerica, MA, USA) using the $\mathrm{CuK} \alpha$ radiation (wavelength $\lambda=1.5418 \AA$ ). The diffraction peaks were broadened by the crystalline size, the intrinsic strains, and instrumental broadening. Crystalline silicon was used as a standard reference specimen to decouple the instrumental contributions. The instrument-corrected broadening $\beta$ corresponding to each diffraction peak of the $\mathrm{Cu}_{x} \mathrm{Zn}_{1-x} \mathrm{O}$ NPs was determined according to Gaussian profile (5) [76].

$$
\beta^{2}=\beta_{m}^{2}-\beta_{i}^{2},
$$


where $\beta$ is the corrected broadening, $\beta_{m}$ is the measured broadening, and $\beta_{i}$ is the instrumental broadening. Then, the corrected physical broadening was used to estimate the crystallite size of $\mathrm{Cu}_{x} \mathrm{Zn}_{1-x} \mathrm{O}$ NPs using the $\mathrm{H}-\mathrm{W}$ method [77]. This method considers both the size and strain effects on the XRD peak broadening and is relevant in the case of Gaussian and Voigt profiles [78]. The crystallite size and strain of the $\mathrm{Cu}_{x} \mathrm{Zn}_{1-x} \mathrm{O}$ NPs were estimated using the $\mathrm{H}-\mathrm{W}$ equation (Equation (6)) [79]:

$$
\left(\beta^{*} / d^{*}\right)^{2}=\frac{1}{\varepsilon}\left(\beta^{*} /\left(d^{*}\right)^{2}\right)+(\eta / 2)^{2},
$$

where $\varepsilon$ is the parameter related to the crystallite size, $\eta$ is the parameter linked to strain, and $\beta^{*}=\beta \cos \theta / \lambda$ and $d^{*}=2 \sin \theta / \lambda$ are the reduced coordinates as a function of the diffraction angle $\theta$ and the wavelength $\lambda$. The $\mathrm{H}-\mathrm{W}$ plots for $\mathrm{Cu}_{x} \mathrm{Zn}_{1-x} \mathrm{O}$ NPs were obtained by plotting $\left(\beta^{*} / d^{*}\right)^{2}$ versus $\beta^{*} /\left(d^{*}\right)^{2}$. The crystalline size, $D$, was obtained from the slope of the fit and the microstrain from the intercept. Furthermore, the lattice parameters $a$ and $c$ of the $\mathrm{Cu}_{x} \mathrm{Zn}_{1-x} \mathrm{O}$ NPs were estimated according to the following Equation (7) [80]:

$$
a=\lambda / \sqrt{3} \sin \theta \text { and } c=\lambda / \sin \theta .
$$

In addition, the dislocation density $\delta$ of the NPs was calculated using Williamson and Smallman's equation (Equation (8)):

$$
\delta=n / D^{2},
$$

where $n$ is a constant that is usually close to one [81].

The morphology and the structure of the synthesized NPs were investigated using HR-TEM with a JEOL JEM 2100F microscope (TEM, Tokyo, Japan) operating at $200 \mathrm{kV}$ (point-to-point resolution of $0.19 \mathrm{~nm}$ ). The samples were prepared by evaporating a diluted suspension of NPs in deionized (DI) water on a carbon-coated copper grid. About 150 NPs were counted to estimate the average size (Image J software, 1.52a, NIH, MD, USA).

FTIR measurements were recorded on a Bruker IFS 28 (Billerica, MA, USA) using the OPUS software (version 3.1) in the $4000-400 \mathrm{~cm}^{-1}$ wavenumber range, with a resolution of $4 \mathrm{~cm}^{-1}$ and a total of 10 scans per measurement. Pellets were made with $1 \mathrm{mg}$ of sample mixed with $150 \mathrm{mg}$ of dried $\mathrm{KBr}$.

Raman spectra were recorded on a Renishaw inVia microspectrometer (Wotton-underEdge, UK) with the $532 \mathrm{~nm}$ excitation line of a doubled $\mathrm{Nd}^{3+}$ YAG laser. The laser beam was focused onto a $10 \mu \mathrm{m}^{2}$ area and the power was kept below $1 \mathrm{~mW}$ to avoid sample heating. The raw spectra were baseline-corrected.

Zeta potentials were measured with a Malvern Zetasizer Nano ZSP instrument (Worcestershire, UK). The suspensions of NPs were prepared in $10^{-2} \mathrm{M} \mathrm{NaCl}$ aqueous solutions. The $\mathrm{pH}$ of the suspension was adjusted from 2 to 12 by adding $\mathrm{HCl}(0.1 \mathrm{M})$ or $\mathrm{NaOH}(0.1 \mathrm{M}$ and $0.01 \mathrm{M})$ solutions.

\subsection{Electrochemical Characterizations}

The electrochemical measurements were performed using a Metrohm Potentiostat Autolab PGSTAT 20 (ECO CHEMIE Ultrecht, The Netherlands) running the Frequency Response Analysis (FRA) and General Purpose Electrochemical System (GPES) software (North Carolina, USA). The measurements were carried out in an electrochemical cell involving a conventional three-electrode system that was equipped with a platinum plate as a counter-electrode, a saturated calomel electrode as the reference electrode, and a sensitive membrane based on $\mathrm{Cu}_{x} \mathrm{Zn}_{1-x} \mathrm{O}$ NPs as the working electrode. All experiments were carried out at $25^{\circ} \mathrm{C}$ using $0.1 \mathrm{M} \mathrm{NaOH}$ as the aqueous electrolyte, which was usually selected for non-enzymatic glucose detection [72,82]. This alkaline medium facilitated the formation of higher oxidized species, such as $\mathrm{Cu}(\mathrm{OH})_{2}$ and $\mathrm{CuOOH}$, which significantly affected the glucose electro-oxidation. Cyclic voltammetry measurements were done with a scan rate of $50 \mathrm{mV} \cdot \mathrm{s}^{-1}$ by cycling the potential from 0 to $0.6 \mathrm{~V}$. Electrochemical impedance 
spectroscopy was performed with a sinusoidal excitation signal with a $10 \mathrm{mV}$ amplitude and the impedance was recorded in the frequency range from 100 to $0.1 \mathrm{~Hz}$. The optimal working potential was adjusted to $0.7 \mathrm{~V}$ (the optimization of the polarization potential is described in supporting information section (Supplementary Materials Figure S3)). The experimental data of the EIS Nyquist plots were fitted with the ZView software. Differential pulse voltammetry peak currents were recorded between 0 and $0.6 \mathrm{~V}$ at a scan rate of $50 \mathrm{mV} \cdot \mathrm{s}^{-1}$. For the glucose detection, multiple solutions of different glucose concentrations were made by following serial dilutions from an initial stock concentration of $10^{-2} \mathrm{M}$. The glucose solutions were tested in increasing concentrations, where the first one was made from the prepared solution of $10^{-6} \mathrm{M}$, which led to a final concentration of $10^{-9} \mathrm{M}$ in the electrochemical cell.

\section{Conclusions}

In summary, the influence of $\mathrm{Cu}$ doping on the physicochemical properties of $\mathrm{ZnO}$ NPs was successfully studied using XRD, TEM, FTIR and Raman spectroscopies, and zeta potential measurements. The use of $\mathrm{Cu}_{x} \mathrm{Zn}_{1-x} \mathrm{O} / \mathrm{ITO}(x=0,0.01,0.02,0.03$, and 0.04$)$ as an electrode material for non-enzymatic glucose sensors was successfully demonstrated. EIS, $\mathrm{CV}$, and DPV analyses of the $\mathrm{Cu}_{x} \mathrm{Zn}_{1-x} \mathrm{O} / \mathrm{ITO}$ modified electrodes showed that copper doping significantly improved the electrochemical properties. Owing to the large surface area and strong adsorption capability, the $\mathrm{Cu}_{0.04} \mathrm{Zn}_{0.96} \mathrm{O} / \mathrm{ITO}$ sensor exhibited an excellent electrocatalytic activity toward glucose in an alkaline medium $(0.1 \mathrm{M} \mathrm{NaOH})$. It exhibited high sensitivity, a low limit of detection, and quantification of glucose over a wide concentration range. Moreover, the selectivity was excellent, as shown by the good resistance to interferences from some common interfering species. The $\mathrm{Cu}_{0.04} \mathrm{Zn}_{0.96} \mathrm{O} / \mathrm{ITO}$ sensing electrode was also suitable for the determination of glucose in human serum samples. This simple, low-cost, and environmentally friendly sensor with excellent detection properties can potentially pave the way for the commercial production of a glucose sensor.

Supplementary Materials: The following are available online. Figure S1: X-ray diffraction analysis of $\mathrm{Cu}_{0.05} \mathrm{Zn}_{0.95} \mathrm{O}$ NPs, Figure S2: Example of the fits of the Nyquist and Bode diagrams of $\mathrm{Cu}_{0.04} \mathrm{Zn}_{0.96} \mathrm{O} / \mathrm{ITO}$, Figure S3: Cyclic voltammograms of $\mathrm{Cu}_{0.05} \mathrm{Zn}_{0.95} \mathrm{O}$ NPs in the absence and presence of glucose, Figure S4: Optimization of the polarization potential for the EIS measurements.

Author Contributions: Conceptualization and methodology, A.M. and M.E.; investigation: A.M., M.E., J.B., and L.S.; writing—original draft preparation: A.M.; writing—review and editing, M.E., N.M., J.B., L.S., and R.B.C.; supervision, project administration, and resources: N.M., R.B.C., and K.O. All authors have read and agreed to the published version of the manuscript.

Funding: This research was funded by the Minister of Higher Education for Scientific Research of Tunisia through a scholarship and it was successfully completed with the financial support received by the Université de Bourgogne and the Conseil Régional Bourgogne Franche-Comté through the Plan d'Actions Régional pour l'Innovation (PARI) and the European Union through the PO FEDERFSE Bourgogne 2014/2020 programs. This work was also supported by the EIPHI Graduate School (contract ANR-17-EURE-0002).

Institutional Review Board Statement: Not applicable.

Informed Consent Statement: Not applicable.

Data Availability Statement: The datasets used and/or analyzed during the current study are available from the corresponding authors on reasonable request.

Acknowledgments: The authors are grateful to Rémi Chassagnon for the TEM investigations (Laboratoire Interdisciplinaire Carnot de Bourgogne (ICB)) and Lionel Maurizi for his support with several characterizations (ICB).

Conflicts of Interest: The authors declare no conflict of interest.

Sample Availability: Samples of the compounds are available from the authors. 


\section{References}

1. Chavali, M.S.; Nikolova, M.P. Metal oxide nanoparticles and their applications in nanotechnology. SN Appl. Sci. 2019, 1, 607. [CrossRef]

2. Ahmad, R.; Tripathy, N.; Ahn, M.-S.; Bhat, K.S.; Mahmoudi, T.; Wang, Y.; Yoon-Bong, H.; Kwon, D.-W.; Yang, H.-Y.; Hahn, Y.-B. Highly Efficient Non-Enzymatic Glucose Sensor Based on CuO Modified Vertically-Grown ZnO Nanorods on Electrode. Sci. Rep. 2017, 7, 1-10. [CrossRef]

3. Phuruangrat, A.; Siri, S.; Wadbua, P.; Thongtem, S.; Thongtem, T. Microwave-assisted synthesis, photocatalysis and antibacterial activity of Ag nanoparticles supported on ZnO flowers. J. Phys. Chem. Solids 2019, 126, 170-177. [CrossRef]

4. Saboor, A.; Shah, S.M.; Hussain, H. Band gap tuning and applications of ZnO nanorods in hybrid solar cell: Ag-doped verses Nd-doped ZnO nanorods. Mater. Sci. Semicond. Process. 2019, 93, 215-225. [CrossRef]

5. Guo, J.; Zhang, J.; Zhu, M.; Ju, D.; Xu, H.; Cao, B. High-performance gas sensor based on ZnO nanowires functionalized by Au nanoparticles. Sens. Actuators B Chem. 2014, 199, 339-345. [CrossRef]

6. Mitta, S.B.; Murahari, P.; Nandanapalli, K.R.; Mudusu, D.; Karuppannan, R.; Whang, D. Si/ZnO heterostructures for efficient diode and water-splitting applications. Int. J. Hydrog. Energy 2018, 43, 16015-16023. [CrossRef]

7. Beitollahi, H.; Tajik, S.; Nejad, F.G.; Safaei, M. Recent advances in ZnO nanostructure-based electrochemical sensors and biosensors. J. Mater. Chem. B 2020, 8, 5826-5844. [CrossRef]

8. Hussain, S.; Braydich-Stolle, L.K.; Schrand, A.M.; Murdock, R.C.; Yu, K.O.; Mattie, D.M.; Schlager, J.J.; Terrones, H. Toxicity Evaluation for Safe Use of Nanomaterials: Recent Achievements and Technical Challenges. Adv. Mater. 2009, 21, 1549-1559. [CrossRef]

9. Aini, B.N.; Siddiquee, S.; Ampon, K.; Rodrigues, K.F.; Suryani, S. Development of glucose biosensor based on ZnO nanoparticles film and glucose oxidase-immobilized eggshell membrane. Sens. Bio-Sensing Res. 2015, 4, 46-56. [CrossRef]

10. Corso, C.D.; Dickherber, A.; Hunt, W.D. An investigation of antibody immobilization methods employing organosilanes on planar ZnO surfaces for biosensor applications. Biosens. Bioelectron. 2008, 24, 805-811. [CrossRef]

11. Hsu, C.-L.; Lin, J.-H.; Hsu, D.-X.; Wang, S.-H.; Lin, S.-Y.; Hsueh, T.-J. Enhanced non-enzymatic glucose biosensor of ZnO nanowires via decorated Pt nanoparticles and illuminated with UV/green light emitting diodes. Sens. Actuators B Chem. 2017, 238, 150-159. [CrossRef]

12. Zhai, C.-H.; Zhang, R.-J.; Chen, X.; Zheng, Y.-X.; Wang, S.-Y.; Liu, J.; Dai, N.; Chen, L.-Y. Effects of Al Doping on the Properties of ZnO Thin Films Deposited by Atomic Layer Deposition. Nanoscale Res. Lett. 2016, 11, 407. [CrossRef]

13. Shatnawi, M.; Alsmadi, A.; Bsoul, I.; Salameh, B.; Mathai, M.; Alnawashi, G.; Alzoubi, G.M.; Al-Dweri, F.; Bawa'Aneh, M. Influence of Mn doping on the magnetic and optical properties of ZnO nanocrystalline particles. Results Phys. 2016, 6, $1064-1071$. [CrossRef]

14. Kati, N. Investigation of Optical and Morphological Properties of Co Doped ZnO Nanomaterials. Turk. J. Sci. Technol. 2019, 14, 41-48.

15. Pascariu, P.; Tudose, I.V.; Suchea, M.; Koudoumas, E.; Fifere, N.; Airinei, A. Preparation and characterization of Ni, Co doped ZnO nanoparticles for photocatalytic applications. Appl. Surf. Sci. 2018, 448, 481-488. [CrossRef]

16. Meshki, M.; Behpour, M.; Masoum, S. Application of Fe doped ZnO nanorods-based modified sensor for determination of sulfamethoxazole and sulfamethizole using chemometric methods in voltammetric studies. J. Electroanal. Chem. 2015, $740,1-7$. [CrossRef]

17. Kim, E.-B.; Ameen, S.; Akhtar, M.S.; Shin, H. Iron-nickel co-doped ZnO nanoparticles as scaffold for field effect transistor sensor: Application in electrochemical detection of hexahydropyridine chemical. Sens. Actuators B Chem. 2018, 275, 422-431. [CrossRef]

18. He, S.; Hou, P.; Petropoulos, E.; Feng, Y.; Yu, Y.; Xue, L.; Yang, L. High Efficient Visible-Light Photocatalytic Performance of $\mathrm{Cu} / \mathrm{ZnO} / \mathrm{rGO}$ Nanocomposite for Decomposing of Aqueous Ammonia and Treatment of Domestic Wastewater. Front. Chem. 2018, 6, 219. [CrossRef]

19. Muthukumaran, S.; Gopalakrishnan, R. Structural, FTIR and photoluminescence studies of Cu doped ZnO nanopowders by co-precipitation method. Opt. Mater. 2012, 34, 1946-1953. [CrossRef]

20. Chakraborty, M.; Ghosh, A.; Thangavel, R. Experimental and theoretical investigations of structural and optical properties of copper doped ZnO nanorods. J. Sol-Gel Sci. Technol. 2015, 74, 756-764. [CrossRef]

21. Othman, A.; Ali, M.A.; Ibrahim, E.; Osman, M. Influence of Cu doping on structural, morphological, photoluminescence, and electrical properties of $\mathrm{ZnO}$ nanostructures synthesized by ice-bath assisted sonochemical method. J. Alloy. Compd. 2016, 683, 399-411. [CrossRef]

22. Lee, H.-J.; Kim, B.-S.; Cho, C.R.; Jeong, S.-Y. A study of magnetic and optical properties of Cu-doped ZnO. Phys. Status Solidi (b) 2004, 241, 1533-1536. [CrossRef]

23. Chandekar, K.V.; Shkir, M.; Al-Shehri, B.M.; Al Faifyb, S.; Halor, R.G.; Khane, A.; Al-Namshah, K.S.; Hamdy, M.S. Visible light sensitive $\mathrm{Cu}$ doped ZnO: Facile synthesis, characterization and high photocatalytic response. Mater. Charact. 2020, 165, 110387. [CrossRef]

24. Ammara, S.; Shamaila, S.; Zafar, N.; Bokhari, A.; Sabah, A.; Shabbir, S.A. Nonenzymatic glucose sensor with high performance electrodeposited nickel/copper/carbon nanotubes nanocomposite electrode. J. Phys. Chem. Solids 2018, 120, 12-19. [CrossRef]

25. Sivasankar, K.; Rani, K.K.; Wang, S.-F.; Devasenathipathy, R.; Lin, C.-H. Copper Nanoparticle and Nitrogen Doped Graphite Oxide Based Biosensor for the Sensitive Determination of Glucose. Nanomaterials 2018, 8, 429. [CrossRef] 
26. Jeong, H.; Nguyen, D.M.; Lee, M.S.; Kim, H.G.; Ko, S.C.; Kwac, L.K. N-doped graphene-carbon nanotube hybrid networks attaching with gold nanoparticles for glucose non-enzymatic sensor. Mater. Sci. Eng. C 2018, 90, 38-45. [CrossRef] [PubMed]

27. Hwang, D.-W.; Lee, S.; Seo, M.; Chung, T.D. Recent advances in electrochemical non-enzymatic glucose sensors-A review. Anal. Chim. Acta 2018, 1033, 1-34. [CrossRef]

28. Fang, L.; Wang, F.; Chen, Z.; Qiu, Y.; Zhai, T.; Hu, M.; Zhang, C.; Huang, K. Flower-like MoS 2 decorated with Cu 2 O nanoparticles for non-enzymatic amperometric sensing of glucose. Talanta 2017, 167, 593-599. [CrossRef] [PubMed]

29. Teymourian, H.; Barfidokht, A.; Wang, J. Electrochemical glucose sensors in diabetes management: An updated review (20102020). Chem. Soc. Rev. 2020, 49, 7671-7709. [CrossRef]

30. Juska, V.B.; Pemble, M.E. A Critical Review of Electrochemical Glucose Sensing: Evolution of Biosensor Platforms Based on Advanced Nanosystems. Sensors 2020, 20, 6013. [CrossRef]

31. Zhu, H.; Li, L.; Zhou, W.; Shao, Z.; Chen, X. Advances in non-enzymatic glucose sensors based on metal oxides. J. Mater. Chem. B 2016, 4, 7333-7349. [CrossRef]

32. Numan, A.; Shahid, M.M.; Omar, F.S.; Ramesh, K.; Ramesh, S. Facile fabrication of cobalt oxide nanograin-decorated reduced graphene oxide composite as ultrasensitive platform for dopamine detection. Sens. Actuators B Chem. 2017, 238, $1043-1051$. [CrossRef]

33. Zhang, H.; Liu, S. Nanoparticles-assembled $\mathrm{NiO}$ nanosheets templated by graphene oxide film for highly sensitive non-enzymatic glucose sensing. Sens. Actuators B Chem. 2017, 238, 788-794. [CrossRef]

34. Park, S.; Boo, H.; Chung, T.D. Electrochemical non-enzymatic glucose sensors. Anal. Chim. Acta 2006, 556, 46-57. [CrossRef] [PubMed]

35. Mahmoud, A.; Echabaane, M.; Omri, K.; El Mir, L.; Ben Chaabane, R. Development of an impedimetric non enzymatic sensor based on $\mathrm{ZnO}$ and $\mathrm{Cu}$ doped $\mathrm{ZnO}$ nanoparticles for the detection of glucose. J. Alloy. Compd. 2019, 786, 960-968. [CrossRef]

36. Singh, B.; Kaushal, A.; Bdikin, I.; Saravanan, K.V.; Ferreira, J.M. Effect of Ni doping on structural and optical properties of Zn 1-x $\mathrm{Ni} x$ O nanopowder synthesized via low cost sono-chemical method. Mater. Res. Bull. 2015, 70, 430-435. [CrossRef]

37. Iribarren, A.; Hernández-Rodríguez, E.; Maqueira, L. Structural, chemical and optical evaluation of Cu-doped ZnO nanoparticles synthesized by an aqueous solution method. Mater. Res. Bull. 2014, 60, 376-381. [CrossRef]

38. Allred, A. Electronegativity values from thermochemical data. J. Inorg. Nucl. Chem. 1961, 17, 215-221. [CrossRef]

39. Singhal, S.; Kaur, J.; Namgyal, T.; Sharma, R. Cu-doped ZnO nanoparticles: Synthesis, structural and electrical properties. Phys. B Condens. Matter 2012, 407, 1223-1226. [CrossRef]

40. Hanh, N.T.; Tri, N.L.M.; Van Thuan, D.; Tung, M.H.T.; Pham, T.-D.; Minh, T.D.; Trang, H.T.; Binh, M.T.; Nguyen, M.V. Monocrotophos pesticide effectively removed by novel visible light driven $\mathrm{Cu}$ doped $\mathrm{ZnO}$ photocatalyst. J. Photochem. Photobiol. A Chem. 2019, 382, 111923. [CrossRef]

41. Slimi, O.; Djouadi, D.; Hammiche, L.; Chelouche, A.; Touam, T. Structural and optical properties of Cu doped ZnO aerogels synthesized in supercritical ethanol. J. Porous Mater. 2017, 25, 595-601. [CrossRef]

42. Rousseau, G.; Fattahi, M.; Grambow, B.; Desgranges, L.; Boucher, F.; Ouvrard, G.; Millot, N.; Niepce, J. Synthesis and characterization of nanometric powders of $\mathrm{UO}_{2+\mathrm{x}},(\mathrm{Th}, \mathrm{U}) \mathrm{O}_{2+\mathrm{x}}$ and $(\mathrm{La}, \mathrm{U}) \mathrm{O}_{2+\mathrm{x}}$. J. Solid State Chem. 2009, 182, 2591-2597. [CrossRef]

43. Mallika, A.; Ramachandrareddy, A.; SowriBabu, K.; Reddy, K.V. Synthesis and optical characterization of aluminum doped ZnO nanoparticles. Ceram. Int. 2014, 40, 12171-12177. [CrossRef]

44. Suwanboon, S.; Amornpitoksuk, P.; Sukolrat, A.; Muensit, N. Optical and photocatalytic properties of La-doped ZnO nanoparticles prepared via precipitation and mechanical milling method. Ceram. Int. 2013, 39, 2811-2819. [CrossRef]

45. Shanmugam, V.; Jeyaperumal, K.S. Investigations of visible light driven Sn and Cu doped ZnO hybrid nanoparticles for photocatalytic performance and antibacterial activity. Appl. Surf. Sci. 2018, 449, 617-630. [CrossRef]

46. Tiwari, N.; Kumar, S.; Ghosh, A.K.; Chatterjee, S.; Jha, S.N.; Bhattacharyya, D. Structural investigations of (Mn, Dy) co-doped ZnO nanocrystals using X-ray absorption studies. RSC Adv. 2017, 7, 56662-56675. [CrossRef]

47. Yogamalar, N.R.; Bose, A.C. Absorption-emission study of hydrothermally grown Al:ZnO nanostructures. J. Alloy. Compd. 2011, 509, 8493-8500. [CrossRef]

48. Murray, D.B.; Netting, C.H.; Saviot, L.; Pighini, C.; Millot, N.; Aymes, D.; Liu, H.-L. Far-Infrared Absorption by Acoustic Phonons in Titanium Dioxide Nanopowders. J. Nanoelectron. Optoelectron. 2006, 1, 92-98. [CrossRef]

49. Arguello, C.A.; Rousseau, D.L.; Porto, S.P.S. First-Order Raman Effect in Wurtzite-Type Crystals. Phys. Rev. 1969, 181, 1351-1363. [CrossRef]

50. Ganesh, R.S.; Navaneethan, M.; Mani, G.K.; Ponnusamy, S.; Tsuchiya, K.; Muthamizhchelvan, C.; Kawasaki, S.; Hayakawa, Y. Influence of Al doping on the structural, morphological, optical, and gas sensing properties of ZnO nanorods. J. Alloy. Compd. 2017, 698, 555-564. [CrossRef]

51. Ghosh, J.; Ghosh, R.; Giri, P.K. Tuning the visible photoluminescence in Al doped ZnO thin film and its application in label-free glucose detection. Sens. Actuators B Chem. 2018, 254, 681-689. [CrossRef]

52. Chow, L.; Lupan, O.; Chai, G.; Khallaf, H.; Ono, L.; Cuenya, B.R.; Tiginyanu, I.; Ursaki, V.; Sontea, V.; Schulte, A. Synthesis and characterization of $\mathrm{Cu}$-doped $\mathrm{ZnO}$ one-dimensional structures for miniaturized sensor applications with faster response. Sensors Actuators A Phys. 2013, 189, 399-408. [CrossRef]

53. Kuriakose, S.; Satpati, B.; Mohapatra, S. Highly efficient photocatalytic degradation of organic dyes by Cu doped ZnO nanostructures. Phys. Chem. Chem. Phys. 2015, 17, 25172-25181. [CrossRef] 
54. Sharma, P.K.; Dutta, R.K.; Pandey, A.C. Doping dependent room-temperature ferromagnetism and structural properties of dilute magnetic semiconductor $\mathrm{ZnO}: \mathrm{Cu}^{2+}$ nanorods. J. Magn. Magn. Mater. 2009, 321, 4001-4005. [CrossRef]

55. Chartier, A.; D'Arco, P.; Dovesi, R.; Saunders, V.R. Ab initio Hartree-Fock investigation of the structural, electronic, and magnetic properties of $\mathrm{Mn}_{3} \mathrm{O}_{4}$. Phys. Rev. B 1999, 60, 14042-14048. [CrossRef]

56. Antony, A.; Poornesh, P.; Kityk, I.V.; Ozga, K.; Jedryka, J.; Rakus, P.; Wojciehcowski, A. X-ray photoelectron spectroscopy, Raman and photoluminescence studies on formation of defects in $\mathrm{Cu}: \mathrm{ZnO}$ thin films and its role in nonlinear optical features. Laser Phys. 2018, 28, 095405. [CrossRef]

57. Zeferino, R.S.; Flores, M.B.; Pal, U.R. Photoluminescence and Raman Scattering in Ag-doped ZnO Nanoparticles. J. Appl. Phys. 2011, 109, 014308. [CrossRef]

58. Li, F.; Liu, X.-C.; Zhou, R.-W.; Chen, H.-M.; Zhuo, S.-Y.; Shi, E.-W. Strong correlation between oxygen vacancy and ferromagnetism in Yb-doped ZnO thin films. J. Appl. Phys. 2014, 116, 243910. [CrossRef]

59. Wang, T.; Yang, W.; Song, T.; Li, C.; Zhang, L.; Wang, H.; Chai, L. Cu doped Fe3O4 magnetic adsorbent for arsenic: Synthesis, property, and sorption application. RSC Adv. 2015, 5, 50011-50018. [CrossRef]

60. Chakraborty, M.; Mahapatra, P.; Thangavel, R. Structural, optical and electrochemical properties of Al and Cu co-doped ZnO nanorods synthesized by a hydrothermal method. Thin Solid Films 2016, 612, 49-54. [CrossRef]

61. Lavanya, N.; Fazio, E.; Neri, F.; Bonavita, A.; Leonardi, S.G.; Neri, G.; Sekar, C. Electrochemical sensor for simultaneous determination of ascorbic acid, uric acid and folic acid based on $\mathrm{Mn}-\mathrm{SnO}_{2}$ nanoparticles modified glassy carbon electrode. $J$. Electroanal. Chem. 2016, 770, 23-32. [CrossRef]

62. Lavanya, N.; Sekar, C.; Ficarra, S.; Tellone, E.; Bonavita, A.; Leonardi, S.G.; Neri, G. A novel disposable electrochemical sensor for determination of carbamazepine based on Fe doped $\mathrm{SnO}_{2}$ nanoparticles modified screen-printed carbon electrode. Mater. Sci. Eng. C 2016, 62, 53-60. [CrossRef] [PubMed]

63. Terbouche, A.; Lameche, S.; Ait-Ramdane-Terbouche, C.; Guerniche, D.; Lerari, D.; Bachari, K.; Hauchard, D. A new electrochemical sensor based on carbon paste electrode/ $\mathrm{Ru}(\mathrm{III})$ complex for determination of nitrite: Electrochemical impedance and cyclic voltammetry measurements. Meas. J. Int. Meas. Confed. IMEKO 2016, 92, 524-533. [CrossRef]

64. De Faria, R.A.D.; Iden, H.; Heneine, L.G.D.; Matencio, T.; Messaddeq, Y. Non-Enzymatic Impedimetric Sensor Based on 3-Aminophenylboronic Acid Functionalized Screen-Printed Carbon Electrode for Highly Sensitive Glucose Detection. Sensors 2019, 19, 1686. [CrossRef] [PubMed]

65. Shrivastava, A.; Gupta, V.B. Methods for the determination of limit of detection and limit of quantitation of the analytical methods. Chron. Young Sci. 2011, 2, 21. [CrossRef]

66. Shahhoseini, L.; Mohammadi, R.; Ghanbari, B.; Shahrokhian, S. Ni(II) 1D-coordination polymer/C60-modified glassy carbon electrode as a highly sensitive non-enzymatic glucose electrochemical sensor. Appl. Surf. Sci. 2019, 478, 361-372. [CrossRef]

67. Khalifa, Z.; Zahran, M.; Zahran, M.A.-H.; Azzem, M.A. Mucilage-capped silver nanoparticles for glucose electrochemical sensing and fuel cell applications. RSC Adv. 2020, 10, 37675-37682. [CrossRef]

68. Xiao, L.; Chen, Q.; Jia, L.; Zhao, Q.; Jiang, J. Networked cobaltous phosphate decorated with nitrogen-doped reduced graphene oxide for non-enzymatic glucose sensing. Sens. Actuators B Chem. 2019, 283, 443-450. [CrossRef]

69. Qian, J.; Wang, Y.; Pan, J.; Chen, Z.; Wang, C.; Chen, J.; Wu, Z.; Yangyue. Non-enzymatic glucose sensor based on ZnO-CeO 2 whiskers. Mater. Chem. Phys. 2020, 239, 122051. [CrossRef]

70. Su, Y.; Guo, H.; Wang, Z.; Long, Y.; Li, W.; Tu, Y. Au@Cu2O core-shell structure for high sensitive non-enzymatic glucose sensor. Sens. Actuators B Chem. 2018, 255, 2510-2519. [CrossRef]

71. Chandrasekaran, N.I.; Manickam, M. A sensitive and selective non-enzymatic glucose sensor with hollow Ni-Al-Mn layered triple hydroxide nanocomposites modified Ni foam. Sens. Actuators B Chem. 2019, 288, 188-194. [CrossRef]

72. Grochowska, K.; Ryl, J.; Karczewski, J.; Śliwiński, G.; Cenian, A.; Siuzdak, K. Non-enzymatic flexible glucose sensing platform based on nanostructured $\mathrm{TiO}_{2}-\mathrm{Au}$ composite. J. Electroanal. Chem. 2019, 837, 230-239. [CrossRef]

73. Jagadeesan, M.; Movlaee, K.; Krishnakumar, T.; Leonardi, S.; Neri, G. One-step microwave-assisted synthesis and characterization of novel $\mathrm{CuO}$ nanodisks for non-enzymatic glucose sensing. J. Electroanal. Chem. 2019, 835, 161-168. [CrossRef]

74. Xu, H.; Xia, C.; Wang, S.; Han, F.; Akbari, M.K.; Hai, Z.; Zhuiykov, S. Electrochemical non-enzymatic glucose sensor based on hierarchical 3D Co3O4/Ni heterostructure electrode for pushing sensitivity boundary to a new limit. Sens. Actuators B Chem. 2018, 267, 93-103. [CrossRef]

75. Omri, K.; Bettaibi, A.; Khirouni, K.; El Mir, L. The optoelectronic properties and role of Cu concentration on the structural and electrical properties of $\mathrm{Cu}$ doped $\mathrm{ZnO}$ nanoparticles. Phys. B Condens. Matter 2018, 537, 167-175. [CrossRef]

76. Nath, D.; Singh, F.; Das, R. X-ray diffraction analysis by Williamson-Hall, Halder-Wagner and size-strain plot methods of CdSe nanoparticles- a comparative study. Mater. Chem. Phys. 2020, 239, 122021. [CrossRef]

77. Halder, N.C.; Wagner, C.N.J. Separation of particle size and lattice strain in integral breadth measurements. Acta Crystallogr. 1966, 20, 312-313. [CrossRef]

78. Millot, N.; Begin-Colin, S.; Perriat, P.; Le Caër, G. Structure, Cation Distribution, and Properties of Nanocrystalline Titanomagnetites Obtained by Mechanosynthesis: Comparison with Soft Chemistry. J. Solid State Chem. 1998, 139, 66-78. [CrossRef]

79. Millot, N.; Aymes, D.; Bernard, F.; Niepce, J.C.; Traverse, A.; Bouree, F.; Cheng, B.L.; Perriat, P. Particle Size Dependency of Ternary Diagrams at the Nanometer Scale: Evidence of $\mathrm{TiO}_{2}$ Clusters in Fe-Based Spinels. J. Phys. Chem. B 2003, 107, 5740-5750. [CrossRef] 
80. Getie, S.; Belay, A.; Chandra Reddy, A.R.; Belay, Z. Synthesis and Characterizations of Zinc Oxide Nanoparticles for Antibacterial Applications. J. Nanomed. Nanotechnol. 2017, 1-8. [CrossRef]

81. Velumani, S.; Narayandass, S.K.; Mangalaraj, D. Structural characterization of hot wall deposited cadmium selenide thin films. Semicond. Sci. Technol. 1998, 13, 1016-1024. [CrossRef]

82. Liu, W.; Chai, G.; Zhao, X.; Dai, Y.; Qi, Y. Effect of different copper sources on the morphology of cuprous oxide and its application as a non-enzymatic glucose sensor. Sens. Actuators B Chem. 2020, 321, 128485. [CrossRef] 